1II) Nordic Council
of Ministers

\title{
ENERGY IN
}

THE WEST NORDICS

AND THE ARCTIC

$+$

CASE STUDIES

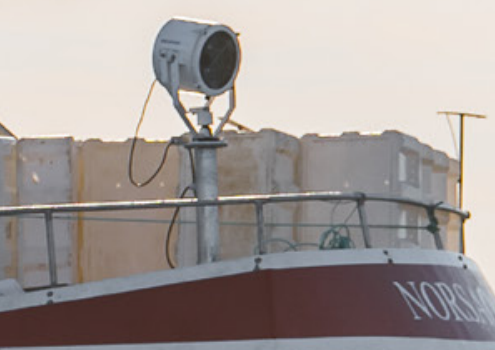

$10 \mathrm{NIJ}$

$\cdot$.

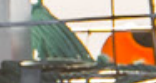

$+i$

R.15-206

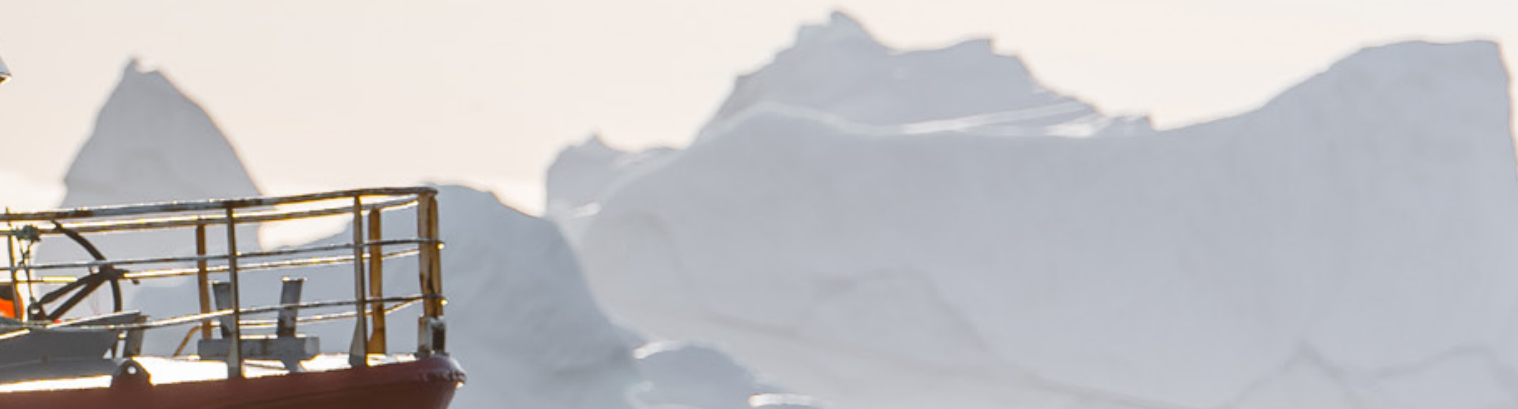

s. 



\section{Energy in the West Nordics and the Arctic}

\section{Case Studies}

Jakob Nymann Rud, Morten Hørmann, Vibeke Hammervold, Ragnar Ásmundsson, Ivo Georgiev, Gillian Dyer, Simon Brøndum Andersen, Jes Erik Jessen, Pia Kvorning and Meta Reimer Brødsted

TemaNord 2018:539 


\section{Energy in the West Nordics and the Arctic}

\section{Case Studies}

Jakob Nymann Rud, Morten Hørmann, Vibeke Hammervold, Ragnar Ásmundsson, Ivo Georgiev, Gillian Dyer,

Simon Brøndum Andersen, Jes Erik Jessen, Pia Kvorning and Meta Reimer Brødsted

ISBN 978-92-893-5703-6 (PRINT)

ISBN 978-92-893-5704-3 (PDF)

ISBN 978-92-893-5705-O (EPUB)

http://dx.doi.org/10.6027/TN2018-539

TemaNord 2018:539

ISSN $0908-6692$

Standard: PDF/UA-1

ISO 14289-1

(c) Nordic Council of Ministers 2018

Cover photo: Mats Bjerde

Print: Rosendahls

Printed in Denmark

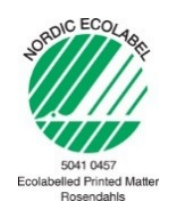

\section{Disclaimer}

This publication was funded by the Nordic Council of Ministers. However, the content does not necessarily reflect the Nordic Council of Ministers' views, opinions, attitudes or recommendations.

\section{Rights and permissions}

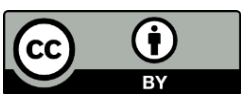

This work is made available under the Creative Commons Attribution 4.0 International license (CC BY 4.0) https://creativecommons.org/licenses/by/4.0

Translations: If you translate this work, please include the following disclaimer: This translation was not produced by the Nordic Council of Ministers and should not be construed as official. The Nordic Council of Ministers cannot be held responsible for the translation or any errors in it.

Adaptations: If you adapt this work, please include the following disclaimer along with the attribution: This is an adaptation of an original work by the Nordic Council of Ministers. Responsibility for the views and opinions expressed in the adaptation rests solely with its author(s). The views and opinions in this adaptation have not been approved by the Nordic Council of Ministers. 
Third-party content: The Nordic Council of Ministers does not necessarily own every single part of this work. The Nordic Council of Ministers cannot, therefore, guarantee that the reuse of third-party content does not infringe the copyright of the third party. If you wish to reuse any third-party content, you bear the risks associated with any such rights violations. You are responsible for determining whether there is a need to obtain permission for the use of third-party content, and if so, for obtaining the relevant permission from the copyright holder. Examples of third-party content may include, but are not limited to, tables, figures or images.

Photo rights (further permission required for reuse):

Any queries regarding rights and licences should be addressed to:

Nordic Council of Ministers/Publication Unit

Ved Stranden 18

DK-1061 Copenhagen K

Denmark

Phone +4533960200

pub@norden.org

\section{Nordic co-operation}

Nordic co-operation is one of the world's most extensive forms of regional collaboration, involving Denmark, Finland, Iceland, Norway, Sweden, and the Faroe Islands, Greenland and Åland.

Nordic co-operation has firm traditions in politics, economics and culture and plays an important role in European and international forums. The Nordic community strives for a strong Nordic Region in a strong Europe.

Nordic co-operation promotes regional interests and values in a global world. The values shared by the Nordic countries help make the region one of the most innovative and competitive in the world.

The Nordic Council of Ministers

Nordens Hus

Ved Stranden 18

DK-1061 Copenhagen K, Denmark

Tel.: +4533960200 www.norden.org

Download Nordic publications at www.norden.org/nordpub 



\section{Contents}

Foreword.

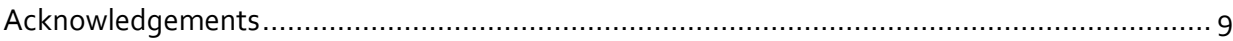

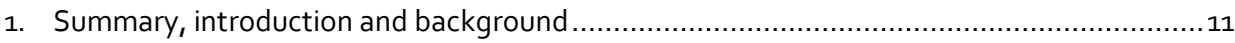

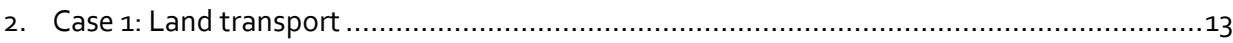

$2.1 \quad$ Current and upcoming technologies ...........................................................

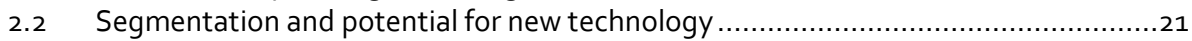

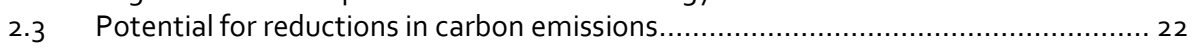

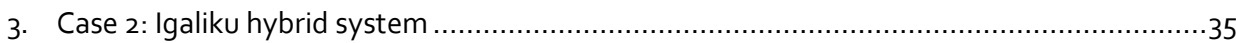

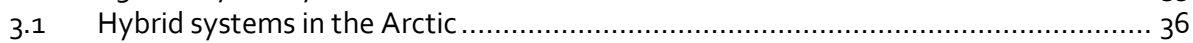

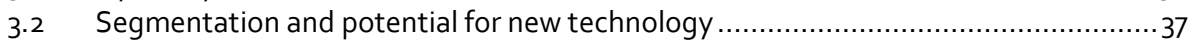

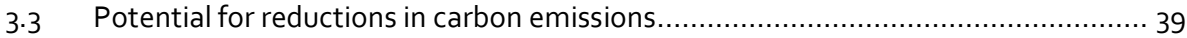

4. Case 3 : Electrification of fishing vessels ............................................................. 41

4.1 Current and upcoming technologies ........................................................... 41

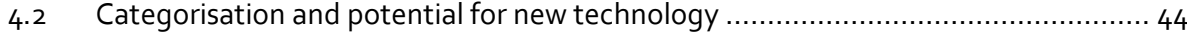

4.3 Potential for reductions in carbon emissions ............................................. 45

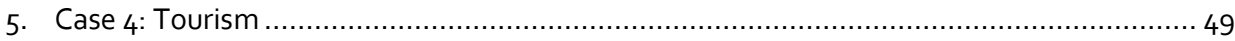

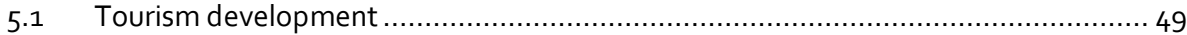

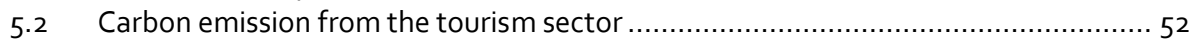

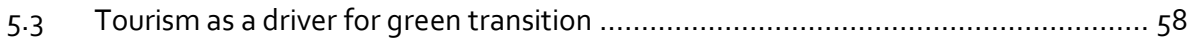

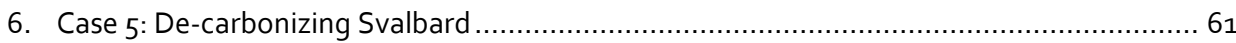

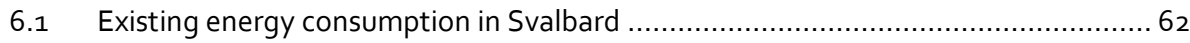

6.2 Catalogue of technical solutions for replacing fossil fuel based energy supply ........ 63

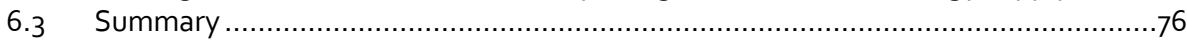



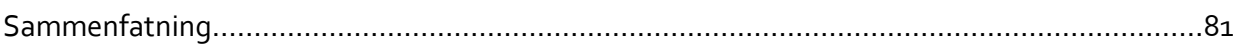

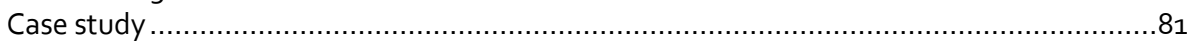

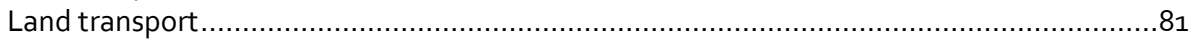

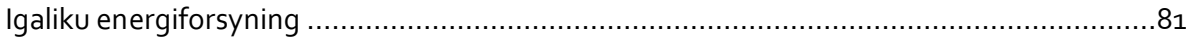



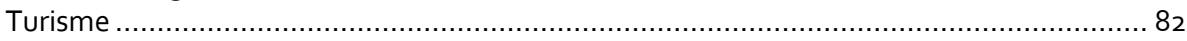

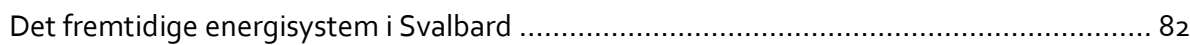





\section{Foreword}

The following report is the result of a study undertaken by COWI on behalf of Nordic Energy Research, the platform for cooperative energy research and policy development under the auspices of Nordic Council of Ministers. Nordic Energy Research's mandate for creating knowledge to support energy and climate targets in the Nordics applies not just to the larger countries of the Nordic region, but also the more sparsely populated areas of the West Artic; Greenland, Iceland, Faroe Islands, Jan Mayen, Svalbard and Arctic Ocean areas nearby these lands. These areas present unique energy challenges, as well as unique opportunities. By studying the energy systems in these areas we can learn how to create a more sustainable, more energy-independent artic region, and begin to apply the lessons learned from these regions to energy systems elsewhere in the world.

We would like to thank all those who have participated in this process.

Hans Jørgen Koch

Director, Nordic Energy Research 



\section{Acknowledgements}

Energy in the West Nordics and the Artic (EVA) is a collaborative project between COWI and Nordic Energy Research - an intergovernmental organisation under the Nordic Council of Ministers.

Nordic Energy Research was the coordinator of the project.

Jakob Nymann Rud at COWI was the project manager and had overall responsibility for the design and implementation of the study.

Nordic Energy Research team

Hilde Marit Kvile, Kevin Johnsen and Marie Kjellén.

\section{COWI team}

Jakob Nymann Rud, Morten Hørmann, Vibeke Hammervold, Ragnar Ásmundsson (HeatRD), Ivo Georgiev, Gillian Dyer, Simon Brøndum Andersen, Jes Erik Jessen, Pia Kvorning, Meta Reimer Brødsted.

\section{Steering group}

The work was guided by the Steering group, consisting of:

Erla Björk Porgeirsdóttir (Iceland), Rune Volla (Norway), Meinhard Eliasen (Faroe Islands), Peter Njenga Githii et al (Greenland).

The individuals and organisations that contributed to this study are not responsible for any opinions or judgements contained in this study. 


\section{Contact}

Comments and questions are welcome and should be addressed to:

Kevin Johnsen

Nordic Energy Research

E-mail: kevin.johnsen@nordicenergy.org

Jakob Nymann Rud

COWI

E-mail: jaru@cowi.com

For enquiries regarding the presentation of results or distribution of the report, contact Nordic Energy Research.

Additional materials, press coverage, presentations etc. can be found at www.nordicenergy.org 


\section{Summary, introduction and background}

This report is a sub report of the project Energy in the West Nordic areas and the Arctic - EVA. The purpose of the projects is to look at the energy situation and the local challenges in the five areas Iceland, Greenland, Faroe Islands, Svalbard and Jan Mayen. Some of the data for the main project (energy situation, energy demand and scenario analysis) will be referred to in this report. The purpose of this report is to develop case studies of five selected challenges which is relevant for the five areas. These are:

- Land transport

- Igaliku hybrid system

- Electrification of fishing vessels

- Tourism

- De-carbonizing Svalbard

The conversion to a sustainable land transportation sector is not an issue for the West Nordic and Arctic areas specifically. However, these specific areas do have a lot of renewable energy potential in wind and hydro power technologies and a transition to electrified (or hydrogen) transportation sector could be an important part of this system.

In Greenland most of the villages are not connected to a common power grid. This calls for more tailored smart energy system solutions. In Igaliku in Greenland, Nukissiorfiit supplies energy to the village town from multiple renewable energy system technologies. This system could be used in many other locations in Greenland.

One of the largest contributors to carbon emissions in the West Nordic and Arctic areas is the fishing industry. The use of renewable energy in the fishing industry (vessels) is not very common. However, electric vessels (batteries or hydrogen fuel cells) could very well be the future in this area.

The West Nordic and Arctic areas are very popular for tourists. This sector is important for the local economies but also challenging with regards to the energy consumption for these areas.

Within the next ten years the local coal mine at Svalbard is expected to be closed. With this the backbone of the energy system at Svalbard - the coal fired power plant will be shut down. This calls for a more comprehensive reconstruction of the energy system but also opens up the possibility for the implementation of renewable energy systems.

These topics will all be presented and discussed in this report. 



\section{Case 1: Land transport}

Reducing carbon emissions from land transport is a challenge anywhere in the world, but more so in the Arctic. Freezing temperatures limit the effectiveness of batteries. Rough terrain and lack of infrastructure increase the dependence on off-road vehicles - a class of vehicle that has typically seen very little attention from hybrid and electric technology developers.

An interesting aspect in the Arctic is the relatively short ranges that land transportation needs to cover, except in Iceland.

In some of more secluded areas distances can be significantly greater than the expected range of electric vehicles. For Greenland this would concern most areas. However, land transportation is rarely used at all outside the major towns of Greenland.

Iceland is a large island with a well-developed road system, so the possible travel distances are long. However, as Reykjavík and the surrounding areas in the southwest of the country are home to over two-thirds of the population, long distances should not be a major problem in relation to everyday use of electric vehicles. The more stable and milder (temperature wise) climate of Iceland and Faroe Islands, compared to the four other regions, will also to some degree limit the challenges with freezing temperatures.

\subsection{Current and upcoming technologies}

To overcome the above-mentioned challenges in the efforts to reduce carbon emissions from land transport, a first step could be to identify and gain insight into current and upcoming technologies that have the potential to be practical under artic conditions.

\subsubsection{Climate hardened batteries and electronics}

Intense efforts are being made in developing new and more efficient battery technology, especially in terms of the ability to store more energy per unit volume, as well as lowering the battery cost per energy unit (improvement of the performance-to-cost ratio). In addition, other efforts to increase the performance of new battery technology are being made, hereunder the development of batteries with the ability to operate at very low temperatures - with still quite satisfying performance.

One apparently promising development in this area was recently made by engineers at the University of California, San Diego. They claim to have developed a breakthrough in electrolyte chemistry that enables lithium batteries to run at 
temperatures as low as $-60^{\circ} \mathrm{C}$, with excellent performance. The new electrolytes also enable electrochemical capacitors to run as low as $-80^{\circ} \mathrm{C} .{ }^{1}$

While the technology enables extreme low temperature operation, high performance at room temperature is still maintained. The new electrolyte chemistry could also increase the energy density and improve the safety of lithium batteries and electrochemical capacitors. ${ }^{2}$

The batteries and electrochemical capacitors that were developed are especially cold-hardy because their electrolytes are made from liquefied gas solvents - gases that are liquefied under moderate pressures - which are more resistant to freezing than standard liquid electrolytes. ${ }^{3}$

However, the technology is not yet mature enough for commercialisation. Thus one of the researchers behind the technology is leading a UC San Diego-based team working to bring it to market via a start-up (called South 8 Technologies).

Another promising development, initially made at Norwegian University of Science and Technology, is now licensed and being further developed by the Norwegian company Graphene Batteries AS. The company is working on a solution that will enable lithium-ion based batteries to run at temperatures down to $-50^{\circ} \mathrm{C}$. Other than this, these batteries will have general properties like common standard lithium-ion based batteries. ${ }^{4}$

The challenge that has been solved, is the development of a special membrane, or rather coating of the usual graphite anode, that allows the use of a special electrolyte with much broader temperature range than usual - an electrolyte that would otherwise deteriorate the anode in absence of the coating/membrane.

Thus, the above mentioned membrane technology is still being developed and is not yet mature for commercialisation. According to the company Graphene Batteries AS, the next step will be the development of a prototype that could attract attention from potential commercial partners that could be interested in production of such batteries with the special membrane technology, based on a license.

\subsubsection{Hydrogen fuel cells for vehicles}

Until recently, cold-weather performance of fuel cells has been prohibitive for their use in cold climates.

A fuel cell basically converts hydrogen into electricity through an electrochemical reaction, with water as a by-product - and the fuel cell membranes can be damaged if water in the cells turns to ice, i.e. under subfreezing temperatures. If ice forms, it can

\footnotetext{
${ }^{1}$ http://ucsdnews.ucsd.edu/pressrelease/electrolytes_made_from_liquefied_gas_enable_batteries_to_run_at_ultra_low

2 The future aim of the researchers is to further improve the energy density and cyclability of both batteries and electrochemical capacitors, and to run them at even lower temperatures.

3 In addition to their exceptional low temperature performance, these electrolytes apparently mitigate a problem called

thermal runaway, which is when the battery gets hot enough to set off a dangerous chain of chemical reactions that in turn

heat up the battery even further. With these new electrolytes, the battery will be unable to self-heat at temperatures much higher than room temperature.

4 https://www.tu.no/artikler/denne-norske-teknologien-kan-gi-elbilbatterier-som-ikke-far-mindre-kapasitet-i-

kulda/408421?utm_source=newsletter-2017-10-03\&utm_medium=email\&utm_campaign=newsletter
} 
reduce the fuel cell performance, damage the cell components, and lead to cold start failure. ${ }^{5}$

However, in recent years, many efforts have been directed at addressing and overcoming the problem with cold start and cold-weather performance of fuel cells.

Example - Toyota fuel cell vehicles have proven fully capable of operating under cold-weather conditions: ${ }^{6}$

- The company Proton OnSite, has 10 Toyota fuel cell hybrid vehicles and operates a hydrogen station for the vehicles and a bus from a nearby community. Even with temperatures as low as $-16^{\circ} \mathrm{C}$, the cars are reported to start up with no issues and the fuelling stations are running without any problems. The vehicles can be fuelled in just a few minutes and can get a range of up to just below $500 \mathrm{~km}$, even in cold weather;

- Also according to Toyota, the Toyota fuel cell vehicles have logged millions of miles in some extreme climates, e.g. where temperatures reach $-30^{\circ} \mathrm{C}$. Fuel cell engineers spent long periods of testing vehicles under such conditions, verifying cold weather start up, performance and durability.

Thus, most technological challenges seem to have been overcome.

However, there are still other challenges to overcome in the dissemination of fuel cell vehicles, such as the current prices of producing hydrogen for fuel cells, and not least the setting up of a sufficient infrastructure network of hydrogen filling stations.

\subsubsection{Off-road vehicles and snowmobiles}

Electric off-road vehicles

There are several off-road plug-in hybrid electric vehicles available on the market already.

These vehicles combine the use of one or more electric motors and a petrol or diesel engine that is also able to function as a generator. They can be used in combined mode or all-electric mode alone.

Among those more common off-road plug-in hybrid electric vehicles already on the market are the Mitsubishi Outlander PHEV, the Volvo XC9o T8 PHEV and the Audi Q7 e-tron quattro PHEV. ${ }^{7}$ They offer all-electric ranges from approximately 40 up to $55 \mathrm{~km}$ - in many cases probably enough for daily use.

\footnotetext{
5 See e.g. "A Comprehensive Review of Solutions and Strategies for Cold Start of Automotive Proton Exchange Membrane Fuel Cells", Amanou et al, IEEE Volume 4, 2016.

${ }^{6}$ https://www.autoblog.com/2014/02/06/toyota-says-freezing-temps-pose-zero-problems-for-fuel-cell-vehi/, http://www.hybridcars.com/toyotas-fuel-cell-vehicles-can-handle-the-cold/

7 Other examples of vehicles in the class that are on the market are: Kia Niro, Lexus RX450h, Toyota RAV 4 Hybrid, Range

Rover Sport Hybrid, Mercedes GLE500e, Lexus NX30oh and BMW X5 XDrive40e.
} 
Also regarding electric off-road vehicles, the $\mathrm{W}_{15}$, a so-called electric rangeextended plug-in pick-up truck is under development by the company Workhorse, ${ }^{8}$ a company focusing on the market for so-called tools of the trade. ${ }^{9}$ The vehicle offers an impressive all-electric range of up to approximately $130 \mathrm{~km}$.

The world's first all-electric all-wheel drive off-road sport utility truck, called $B_{1}$, is claimed to have been developed by the New York-based start-up company Bollinger Motors. ${ }^{10}$ The vehicle is stated to be equipped with two options for battery packs, providing ranges of either up to $195 \mathrm{~km}$ or around $320 \mathrm{~km}$.

In addition to the above-mentioned developments, Ford has decided to redeploy a significant amount of its development capital from internal-combustion engines to investments in electrification - including the setting up of a dedicated electrification team. Thus, Ford plans to deliver 13 new electrified vehicles in the next five years, including F-150 and Mustang hybrids, a Transit Custom plug-in hybrid, and a fully electric small SUV. ${ }^{11}$

See Table 1 below for a summary of more technical specifications of the abovementioned off-road vehicles.

Table 1: Summary of technical specifications - electric off-road vehicles

\begin{tabular}{|c|c|c|c|c|c|c|}
\hline Brand/Model & Type & $\begin{array}{r}\text { Battery pack [kWh] } \\
\text { (range up to }[\mathrm{km}] \text { ) }\end{array}$ & Power train [hp] & $\begin{array}{r}\text { Charging [hours ] } \\
\text { Fast-charging [min.] }\end{array}$ & Market state & $\begin{array}{l}\text { Practical } \\
\text { experience }\end{array}$ \\
\hline $\begin{array}{l}\text { Mitsubishi } \\
\text { Outlander PHEV }\end{array}$ & Plug-in hybrid & $12(52)$ & $\begin{array}{l}164 \text { electric (combined } \\
\text { with } 121 \text { gasoline) }\end{array}$ & $\begin{array}{r}3.5-13 \mathrm{hrs} . \\
25 \mathrm{~min} .\end{array}$ & On market & $\begin{array}{l}\text { Marketed for } \\
\text { some years - } \\
\text { popular in } \\
\text { Norway }\end{array}$ \\
\hline $\begin{array}{l}\text { Volvo XC9o T8 } \\
\text { PHEV }\end{array}$ & Plug-in hybrid & $10.4(40)$ & $\begin{array}{l}87 \text { electric (combined } \\
\text { with } 320 \text { gasoline) }\end{array}$ & $\begin{array}{r}\sim 2.5 \mathrm{hrs} . \\
\mathrm{n} / \mathrm{a}\end{array}$ & On market & \\
\hline $\begin{array}{l}\text { Audi } \text { O7 e-tron } \\
\text { quattro PHEV }\end{array}$ & Plug-in hybrid & $17.3(56)$ & $\begin{array}{l}126 \text { electric (combined } \\
\text { with } 258 \text { diesel) }\end{array}$ & $\begin{array}{r}2.5-8 \mathrm{hrs} . \\
\mathrm{n} / \mathrm{a}\end{array}$ & On market & \\
\hline Workhorse W15 & $\begin{array}{l}\text { Plug-in hybrid } \\
\text { (range-extended) }\end{array}$ & $60(130)$ & 460 & $\mathrm{n} / \mathrm{a}$ & $\begin{array}{l}\text { Prototype- } \\
\text { targeted for } \\
\text { production } 2018\end{array}$ & \\
\hline Bollinger $B_{1}$ & All-electric & $60 / 100(195 / 320)$ & 360 & $\begin{array}{l}7 / 12 \mathrm{hrs} . \\
45 / 75 \mathrm{~min} .\end{array}$ & $\begin{array}{l}\text { Prototype (seeking } \\
\text { manufacturing } \\
\text { partner) }\end{array}$ & \\
\hline
\end{tabular}

\footnotetext{
${ }^{8}$ Where a gasoline engine - unusually - will function only as a generator to feed the electric drive-train/motors.

9 Carrying supplies for construction or utility projects, for instance, or getting workers and their tools from one job site to the next.

${ }^{10}$ http://www.roadandtrack.com/new-cars/car-technology/a10375356/this-electric-truck-is-the-future-of-off-roading/, http://bollingermotors.com/

${ }^{11} \mathrm{http} / / /$ www.roadandtrack.com/new-cars/future-cars/a12844641/expect-more-off-road-and-electrified-vehicles-fromford/
} 


\section{Electric snowmobile}

The Canadian start-up company Taiga Motors has developed an all-electric snowmobile.

The company claims that its snowmobile is capable of running at $95 \%$ capacity at temperatures as cold as $-40^{\circ} \mathrm{C}$. The snowmobile has a claimed range of up to $100 \mathrm{~km}$ and a capability to accelerate from 0 to $100 \mathrm{~km} / \mathrm{h}$ in approximately 3 seconds. Recharging the battery can apparently be done in as little as 50 minutes, thanks to a "rapid recharge" capability. The stated weight is approximately $230 \mathrm{~kg} .{ }^{12}$

Two Canadian adventure tour companies have initially tested a prototype of the electric snowmobile this past winter, and a larger-scale test of up to 10 electric snowmobiles will be undertaken this coming winter - primarily at ski resorts though, where the area to cover is relatively limited and charging can be arranged at existing facilities. ${ }^{13}$

\subsubsection{Buses and Lorries}

\section{Electric or fuel cell powered buses}

Several companies have introduced busses, primarily suited for bus transport in urban areas where distances are short to moderate.

One of these companies is the Finnish company Linkker. ${ }^{14}$ They have constructed the Linkker 12+, a fast-charging electric bus, in which batteries are charged at end stops while passengers board (not only charged at depots overnight) - where the batteries only need about 1.5-3 minutes to charge.

Due to the fast-charging system, the batteries of the buses are smaller in size, so the buses are lighter and thus, the weight does not limit passenger capacity. In addition, the buses have a full-aluminium body so they are light compared to buses made from steel.

The busses have a maximum capacity of up to 80 passengers, with a typical configuration of 38 seats and up to 42 standing rooms.

The buses are claimed to be highly energy-efficient using only $1.05 \mathrm{kWh}$ per kilometre (compared to over $3 \mathrm{kWh}$ per kilometre for traditional diesel buses).

The typical range amounts to a daily mileage of more than $300 \mathrm{~km}-1$ full charge gives a range of 30-50 km, while every 2 minutes of fast-charging gives a range of approximately $10 \mathrm{~km}$. Fast-charging is done using a roof connected pantograph, while full changing overnight is done using a traditional plug in connection.

According to the Linkker company, buses are claimed to be engineered for operation in cold (as well as hot) climate conditions, hereunder operation below $-25^{\circ} \mathrm{C}$. They are equipped with energy efficient auxiliaries, to deal with heavy snowfall, and have insulated and double-glazed bodies providing stable operation in harsh climatic conditions.

\footnotetext{
12 http://cs.amsnow.com/sno/b/news/archive/2017/04/21/electric-snowmobile-here-to-stay.aspx

${ }_{13} \mathrm{https}$ ://electrek.co/2017/04/18/all-electric-snowmobiles-taiga-motors/

14 http://www.linkkerbus.com/technology/
} 
These Linkker buses service one central bus line in Turku, Finland $-12.4 \mathrm{~km}$ in length - and another bus line in Espoo, Finland - $19.2 \mathrm{~km}$ in length - with an average energy consumption around $0.9 \mathrm{kWh} / \mathrm{km}$. The buses are also operating on one bus line in a pilot test project in Copenhagen, Denmark, and on two bus lines in Helsinki, Finland. Recently the buses were introduced for field tests to gain experience on one route in Berlin, Germany, and on a number of inner city routes in Moscow, Russia. ${ }^{15}$

The Swedish car, lorry and bus manufacturer Volvo has also developed a fullelectric bus, the Volvo 7900 electric citybus. ${ }^{16}$ This bus uses similar technological principles, where fast-charging or opportunity charging and a lightweight aluminium body means that a smaller and lighter battery pack can be used, resulting in higher passenger capacity, and increasing both range and operational hours.

The passenger capacity is reported to be up to a maximum of 105 passengers, though with a maximum number of 34 seats.

The energy efficiency of the electric buses is stated to be heavily dependent on the driving pattern at the specific route, terrain/topography and loads, but would be approximately in the order of $1.2 \mathrm{kWh} / \mathrm{km}$ (relatively flat terrain) to $1.4 \mathrm{kWh} / \mathrm{km} .{ }^{17}$

Buses are primarily sold as part of a complete "electrification" project of e.g. a specific route, thus including a number of buses and the necessary opportunity charging infrastructure (at strategically selected stops) etc. Thus, prices will depend on a number of factors. However, an approximate price for one bus is purported to be in the order of EUR 505,000 to EUR 533,000, while an approximate price for one fast-charging facility is claimed to be in the order of EUR 200,000. ${ }^{18}$

Since 2015 , the buses have been operated on one bus line as part of the ElectriCity pilot project in Gothenburg, Sweden, that was recently expanded. According to Volvo Buses, these fully electric buses have also been ordered for operation in the cities Malmö (Sweden), Differdange (Luxemburg), and Harrogate (UK). Recently an order has been placed for 25 fully electric Volvo 7900 Electric buses for operation in the city of Trondheim, Norway, starting in August 2019. ${ }^{19}$

The Volvo 7900 is also manufactured in two different hybrid bus versions.

Following another technological line, Toyota has unveiled a fuel cell bus concept, that the company plans to introduce in over 100 fully functioning units to operate within the Tokyo metropolitan area before the Tokyo 2020 Olympic and Paralympic Games.

The bus should be able to carry 78 passengers ( 22 seated, 56 standing) plus the driver. $^{20}$

See Table 2 below for a summary of more technical specifications of the abovementioned buses.

\footnotetext{
15 http://www.linkkerbus.com/updates/

${ }^{16}$ http://www.volvobuses.co.uk/en-gb/our-offering/buses/volvo-79oo-electric.html

${ }_{17}$ Personal communication, Jan Bredo, Volvo Bus Denmark.

${ }^{18}$ Personal communication, Jan Bredo, Volvo Bus Denmark.

19 http://www.volvobuses.com/en-en/news/2017/sep/Volvo-receives-largest-ever-order-of-fully-electric-buses-fortrondheim.html

${ }^{20} \mathrm{http}: / /$ newsroom.toyota.co.jp/en/detail/15160167, https://newatlas.com/toyota-sora-fuel-cell-bus-tokyo/51825/, https://paultan.org/2017/10/20/toyota-sora-fuel-cell-bus-concept-with-200-km-range/
} 
Table 2: Summary of technical specifications - electric and fuel cell buses

\begin{tabular}{|c|c|c|c|c|c|c|}
\hline Brand/Model & Type & $\begin{array}{r}\text { Battery } \\
\text { pack/energy } \\
\text { content }[\mathrm{kWh}] \\
\text { (range up to }[\mathrm{km}])\end{array}$ & $\begin{array}{r}\text { Power } \\
\text { train [hp] }\end{array}$ & $\begin{array}{r}\text { Charging } \\
\text { [hours] } \\
\text { Fast-charging } \\
\text { [min.] }\end{array}$ & Market state & Practical experience \\
\hline Linkker $12+$ bus & $\begin{array}{l}\text { All- } \\
\text { electric }\end{array}$ & $\begin{array}{l}55 / 63.5 \\
(30-50)^{3}\end{array}$ & 240 & $\begin{array}{r}6-8 \text { hrs. }^{1} \\
1.5-3 \text { min. }^{2}\end{array}$ & On market & $\begin{array}{l}\text { Operates on selected } \\
\text { bus lines in more cities. } \\
\text { Pilot testing and/or field } \\
\text { testing in several other } \\
\text { cities }\end{array}$ \\
\hline $\begin{array}{l}\text { Volvo } 7900 \\
\text { electric citybus }\end{array}$ & $\begin{array}{l}\text { All- } \\
\text { electric }\end{array}$ & 764 & 215 & $\begin{array}{r}n / a \\
3-6 \text { min. }{ }^{2}\end{array}$ & On market & $\begin{array}{l}\text { Operated on pilot } \\
\text { project for several years. } \\
\text { Ordered for operation in } \\
\text { a number of cities }\end{array}$ \\
\hline $\begin{array}{l}\text { Toyota Sora } \\
\text { fuel cell bus }\end{array}$ & Fuel cell & $\begin{array}{r}235^{5} \\
(200)\end{array}$ & $2 \times 152$ & $\begin{array}{r}\mathrm{n} / \mathrm{a} \\
10 \mathrm{~min}^{6}\end{array}$ & Prototype & $\begin{array}{l}\text { To be introduced in over } \\
100 \text { fully functioning } \\
\text { units }\end{array}$ \\
\hline
\end{tabular}

Note: ${ }^{1}$ Full charge overnight at depots.

${ }^{2}$ Opportunity-charging at selected stops.

3 One full charge.

${ }^{4} \mathrm{~A} 250 \mathrm{kWh}$ battery pack to be introduced in 2019.

${ }^{5}$ Fuel tank energy storage capacity.

${ }^{6}$ Refuelling of tanks.

\section{Electric or fuel cell powered lorries/trucks}

One of the first fully electric trucks has been presented by Mercedes-Benz, the so-called Urban eTruck ${ }^{21}$ - primarily suited for distribution. Recently, it was decided to bring the all-electric heavy-duty truck to market in a small series for delivery this year, to further optimise the vehicle concept and the system configurations of the electric truck through actual application scenarios. ${ }^{22}$

Previously, Mercedes-Benz introduced the Fuso Canter E-Cell, now called the Fuso eCanter, a fully electric-powered small/light truck. ${ }^{23}$ Since April 2016, the German city of Stuttgart and the parcel service provider Hermes have been testing five FUSO Canter E-Cells. Stuttgart is a very topographically demanding urban environment, and these tests should provide important insights to help the further development of the fully electric drive in the Fuso eCanter.

Similar all-electric small and medium duty trucks have been introduced by the Australian manufacturer SEA Electric - the SEA EV 10 and the SEA EV $14 .{ }^{24}$

Recently, Daimler unveiled a new all-electric heavy-duty concept truck called the E-FUSO Vision ONE. 25

\footnotetext{
${ }^{21} \mathrm{https} / / /$ www.daimler.com/products/trucks/mercedes-benz/world-premiere-mercedes-benz-electric-truck.html

22 https://www.mercedes-benz.com/en/mercedes-benz/next/e-mobility/e-truck-rolls-in-series/

$23 \mathrm{https} / / / \mathrm{www}$.daimler.com/products/trucks/fuso/ecanter.html

$24 \mathrm{http}: / /$ www.sea-electric.com/ev-10/, http://www.sea-electric.com/ev-14/

25 https://electrek.co/2017/10/25/daimler-heavy-duty-electric-truck-concept/,

https://www.daimler.com/innovation/case/electric/efuso-2.html
} 
Also very recently, Tesla unveiled its Class 8 electric truck. Although not many details about the exact technical specifications have been revealed yet.

Based on fuel cell technology Toyota has developed a heavy-duty truck (so-called class 8 truck). A concept version of the truck is running short-haul routes at the Port of Los Angeles as part of a feasibility study. ${ }^{26}$

And the American start-up company Nikola Motor Co. has announced plans to begin field tests of its hydrogen fuel cell heavy truck next fall. Full production is expected to start in $2021 .{ }^{27}$

See Table 3 below for a summary of more technical specifications of the abovementioned trucks.

Table 3: Summary of technical specifications - electric and fuel cell trucks

\begin{tabular}{|c|c|c|c|c|c|c|}
\hline Brand/Model & Type & $\begin{array}{r}\text { Battery } \\
\text { pack/energy } \\
\text { content }[\mathrm{kWh}] \\
\text { (range up to }[\mathrm{km}] \text { ) }\end{array}$ & $\begin{array}{r}\text { Power train } \\
\text { [hp] }\end{array}$ & $\begin{array}{r}\text { Charging [hours] } \\
\text { Fast-charging [min.] }\end{array}$ & Market state & Practical experience \\
\hline $\begin{array}{l}\text { Mercedes-Benz Urban } \\
\text { eTruck (heavy-duty) }\end{array}$ & All-electric & $\begin{array}{r}212 \\
(200)\end{array}$ & $\mathrm{n} / \mathrm{a}$ & 3 hrs. $^{1}$ & $\begin{array}{l}\text { To be introduced in } \\
\text { small series }\end{array}$ & $\begin{array}{l}\text { To be further optimised } \\
\text { through actual application } \\
\text { scenarios }\end{array}$ \\
\hline $\begin{array}{l}\text { Mercedes-Benz Fuso } \\
\text { eCanter (light) }\end{array}$ & All-electric & $\begin{array}{r}70 \\
(100)\end{array}$ & $\mathrm{n} / \mathrm{a}$ & $\begin{array}{l}7 \mathrm{hrs} \text {. } \\
60 \mathrm{~min} \text {. }\end{array}$ & First trucks delivered & $\begin{array}{l}\text { Testing under actual } \\
\text { application scenarios }\end{array}$ \\
\hline $\begin{array}{l}\text { SEA Electric, SEA } \\
\text { EV10 (light) }^{\text {ligh }}\end{array}$ & All-electric & $\begin{array}{r}120 \\
(180)\end{array}$ & $\mathrm{n} / \mathrm{a}$ & $6 \mathrm{hrs}$. & First trucks delivered & \\
\hline $\begin{array}{l}\text { SEA Electric, SEA } \\
\text { EV14 (medium) }\end{array}$ & All-electric & $\begin{array}{r}140 \\
(180)\end{array}$ & $\mathrm{n} / \mathrm{a}$ & 6-7 hrs. & First trucks delivered & \\
\hline $\begin{array}{l}\text { Daimler E-FUSO } \\
\text { Vision ONE (heavy- } \\
\text { duty) }\end{array}$ & All-electric & $\begin{array}{r}300 \\
(350)\end{array}$ & $\mathrm{n} / \mathrm{a}$ & $\mathrm{n} / \mathrm{a}$ & $\begin{array}{l}\text { Prototype-Market } \\
\text { entry within } 4 \text { years }\end{array}$ & \\
\hline $\begin{array}{l}\text { Tesla Semi (heavy- } \\
\text { duty) }\end{array}$ & All-electric & $\begin{array}{r}n / a \\
(800)\end{array}$ & $\mathrm{n} / \mathrm{a}$ & $\begin{array}{r}n / a \\
80 \% \text { of capacity } \\
\text { within } 30 \text { min. }^{2}\end{array}$ & $\begin{array}{l}\text { Expected in production } \\
\text { by } 2019\end{array}$ & $\begin{array}{l}\text { More than } 200 \text { vehicles pre- } \\
\text { ordered by e.g. UPS and } \\
\text { PepsiCo }\end{array}$ \\
\hline $\begin{array}{l}\text { Toyota fuel cell truck } \\
\text { (heavy-duty) }\end{array}$ & Fuel cell & $\begin{array}{r}n / a \\
(385)\end{array}$ & 675 & $30 \mathrm{~min}$. & Concept version & $\begin{array}{l}\text { Running short-haul routes } \\
\text { at the Port of Los Angeles as } \\
\text { part of a feasibility study }\end{array}$ \\
\hline $\begin{array}{l}\text { Nikola One (heavy- } \\
\text { duty) }\end{array}$ & Fuel cell & $\begin{array}{r}n / a \\
(1,300-1,900)\end{array}$ & 1,000 & $15 \mathrm{~min}$. & $\begin{array}{l}\text { Prototype-production } \\
\text { expected from } 2021\end{array}$ & $\begin{array}{l}\text { Field tests planned from fall } \\
2018\end{array}$ \\
\hline
\end{tabular}

Note: $\quad{ }^{1}$ With special fast-charger.

${ }^{2}$ With a special so-called "mega-charger".

\footnotetext{
${ }^{26}$ https://www.trucks.com/2017/04/19/toyota-project-portal-fuel-cell-truck-technology/, https://www.theverge.com/2017/10/12/16461412/toyota-hydrogen-fuel-cell-truck-port-la

27 https://www.trucks.com/2017/11/og/nikola-fuel-cell-truck-field-test-2018/, https://arstechnica.com/cars/2017/09/nikolamotor-company-and-bosch-team-up-on-long-haul-fuel-cell-truck/, https://nikolamotor.com/one
} 


\subsection{Segmentation and potential for new technology}

\subsubsection{Segmentation}

Primarily based on data from official statistical bureaus of the Arctic regions under consideration, we find the fleet of land/road transport vehicles reported below in Table 4 .

Table 4: Number of vehicles according to vehicle type, 2016

\begin{tabular}{lrrrrr} 
Vehicle type & Iceland & Faroe Islands & Greenland & Svalbard & Jan Mayen \\
Cars & 240,490 & 22,293 & 4,375 & 754 & 11 \\
Buses & 2,862 & 211 & 76 & 0 & 0 \\
Vans & 24,508 & 3,685 & 993 & 0 & 0 \\
Trucks/lorries & 11,064 & 562 & 322 & 0 & 2 \\
Snowmobiles & 5,255 & 0 & 1,179 & 1,355 & 0 \\
ATV \& 4-whl.1 & 19,140 & 2,546 & 7,154 & 2,109 & 0 \\
Total & 303,319 & 29,297 & & 16 \\
\hline
\end{tabular}

Note: ${ }^{1}$ Including motorcycles and mopeds.

${ }^{2} 2014$ data.

As in most other countries cars are the dominating vehicle type. In Iceland and the Faroe Islands and to some degree Greenland there are also a significant number of vans. In Iceland there are a relatively high number of trucks/lorries and buses.

Snowmobiles seem to play an important role in Greenland and Svalbard and to some extent in Iceland. In Iceland, as well as the Faroe Islands, ATVs (including motorcycles) seem to be of some importance. ${ }^{28}$

The overall energy consumption from land/road transport is reported below in Table 5 , based on data gathered in the main project. As can be seen from the table, we have not been able to obtain or estimate data for Jan Mayen on the consumption of energy specifically for land transport.

Table 5: Estimated energy consumption for land transport, 2016

\begin{tabular}{llccccc} 
[PJ] & & Iceland & Faroe Islands & Greenland & Svalbard & Jan Mayen \\
\hline Diesel oil & DSL & 5.4340 & 0.8300 & 0.2500 & 0.0105 & NA \\
Motor spirit & GSL & 5.6960 & 0.4500 & 0.2750 & 0.0637 & NA \\
Biogas & BGS & 0.1090 & 0.0000 & 0.0000 & 0.0000 & NA \\
\hline
\end{tabular}

${ }^{28}$ It should be noted that the category ATV and 4-wheeler does include a large number of motorcycles (app. 50\%) and some mopeds. 
As the table shows, the absolutely dominating fuels are diesel oil and motor spirit. Only in Iceland does there seem to be a minor use of biogas for land/road transport.

Potential for new technology

Based on the previous examination of the current state of technological development regarding climate hardened batteries and fuel cells as well as electric or fuel cell based vehicles, it appears that such technologies and vehicle types are developing rapidly.

Thus, we will assume that technologies/vehicles will be further developed and matured for market entry, within a reasonable time horizon. Nevertheless, although costs are assumed to decline as technologies are developing, our data sources indicate that cost levels will still be above cost levels of conventional technologies.

Following a general segmentation of vehicles in the relevant regions under consideration, and an estimation of the overall energy consumption for land/road transport, we will estimate the potential for carbon emissions reductions and the associated extra socio-economic costs.

This estimate will be based on the assumption that it will be possible to replace the entire fleet of conventional land/road transport vehicles in all the relevant Arctic regions, with emissions-free land/road transport vehicles based on electric or fuel cell technology.

\subsection{Potential for reductions in carbon emissions}

Based on the above assumption, we could estimate the potential for reductions in carbon emissions from conventional land/road transport as the carbon emissions from the overall fossil based energy consumption for land/road transport.

However, we estimate the potential for reductions in carbon emissions from conventional land/road transport according to type of vehicle and fuel used.

\subsubsection{Methodology for estimation of reduction potential and associated costs}

Thus, based on the segmentation of numbers and overall types of vehicles in each of the relevant regions, we estimate the number of vehicles according to type of vehicle and type of fuel. It has only been possible to obtain small amounts of data on the exact distribution of certain vehicle types according to fuel. Thus, our estimation is to some extent based on rough assumptions on the distribution of specific conventional vehicles according to fuel; e.g. assumptions that buses and lorries/trucks are running on diesel only, and that snowmobiles are running on gasoline/motor spirit only.

Thus, having estimated the number of vehicles according to type of vehicle and type of fuel, we calculate a "bottom-up" approximation of the total energy consumption of land/road transport vehicles according to vehicle type and type of fuel. The calculation will be based on standard assumptions on the annual driven 
distance for each type of vehicle, as well as data on the specific energy consumption for standard vehicles of the relevant type. ${ }^{29}$

This bottom-up calculated energy consumption is then used as a key to relatively distribute the actual overall energy consumption for land/road transport according to vehicle type and type of fuel.

Based on standard emission factors for the relevant types of conventional fuels used for land/road transport we then estimate the actual carbon emissions from land/road transport according to vehicle type and type of fuel. These actual carbon emissions also represent the emissions reduction potential, based on the initially mentioned assumption that it will be possible to replace the entire fleet of conventional land/road transport vehicles in all the relevant Arctic regions with emissions-free land/road transport vehicles based on electric or fuel cell technology.

A similar approach is then used for calculating the projected energy consumption and carbon emissions/reduction potential in 2020 and 2035, taking the projected development in energy efficiency of conventional standard vehicles into account (keeping number and distribution of vehicles as well as assumed annual driven distance constant).

Finally, we will try to estimate the annual extra socio-economic costs associated with a total replacement of the entire fleet of conventional land/road transport vehicles in the relevant Arctic regions with emissions-free road transport vehicles based on electric or fuel cell technology:

- First, we estimate the total annual socio-economic costs (including fuels) of operating the current fleet of conventional land/road transport vehicles in each of the relevant Arctic regions. The estimate is based on annualized expected/projected costs of standard conventional vehicles according to each relevant type of vehicle and fuel type as well as expected/projected costs of relevant fuels;

- Second, we similarly estimate the total annual socio-economic costs (including fuels) of operating a corresponding fleet of emissions-free land/road transport vehicles based on electric or fuel cell technology in each of the relevant Arctic regions. We base this estimate on an assumption that the majority of conventional vehicles will be replaced with electric vehicles, although some conventional vehicles are replaced with fuel cell vehicles better suited for longer distances. Further, we base the estimate on annualized expected costs of emissions-free land/road transport based on electric or fuel cell technology according to relevant types of vehicles and fuels, taking into account projected development of such vehicle costs and fuel costs. These expected vehicle costs are adjusted by assumed additional costs of climate-hardened technologies;

\footnotetext{
29 As we have not been able to obtain specific data on e.g. annual average distances driven these are the best available data. And as the bottom up calculated energy consumption based on these data does, in most cases, reasonably fit the actual estimated energy consumption, we find it a fair approximation. Further, as the bottom up calculated energy consumption is used as a key for distribution of the actual estimated energy consumption, the absolute numbers are of less importance than the relative numbers.
} 
- Third, the extra annual socio-economic costs associated with a total replacement of the entire fleet of conventional land/road transport vehicles with emissions-free land/road transport vehicles based on electric or fuel cell technology, is estimated as the difference between the two abovementioned cost estimates.

\subsubsection{Iceland}

Regarding Iceland, we have obtained data on the number of cars and vans and divided them according to diesel, gasoline and other fuels. Thus, based on the overall segmentation of conventional vehicles according to vehicle type we estimate the number of land/road transport vehicles according to vehicle type and type of fuel as shown below in Table 6 .

Table 6: Number of vehicles according to vehicle type and fuel, Iceland

\begin{tabular}{|c|c|c|c|c|}
\hline Vehicle type & $\begin{array}{c}\text { Diesel oil } \\
\text { DSL }\end{array}$ & $\begin{array}{r}\text { Motor spirit } \\
\text { GSL }\end{array}$ & $\begin{array}{r}\text { Biogas } \\
\text { BGS }\end{array}$ & Total \\
\hline Cars & 67,337 & 170,748 & 2,405 & 240,490 \\
\hline Buses & 2,862 & 0 & 0 & 2,862 \\
\hline Vans & 17,401 & 7,107 & 0 & 24,508 \\
\hline Trucks/lorries & 11,064 & 0 & 0 & 11,064 \\
\hline Snowmobiles & 0 & 5,255 & 0 & 5,255 \\
\hline ATV \& 4-whl. & 0 & 19,140 & 0 & 19,140 \\
\hline Total & 98,664 & 202,250 & 2,405 & 303,319 \\
\hline
\end{tabular}

\section{Energy consumption and related emissions}

Based on the above outlined methodology we then estimate the current and projected energy consumption by land/road transport according to vehicle type and type of fuel in Iceland shown below in Table 7.

Table 7: Current and projected energy consumption by land transport [TJ], Iceland

\begin{tabular}{|c|c|c|c|c|c|c|c|c|c|c|c|c|}
\hline \multirow{2}{*}{ [TJ] } & \multicolumn{4}{|c|}{2016} & \multicolumn{4}{|c|}{2020} & \multicolumn{4}{|c|}{2035} \\
\hline & DSL & GSL & BGS & Total & DSL & GSL & BGS & Total & DSL & GSL & BGS & Total \\
\hline Cars & 1,470 & 5,173 & 109 & 6,752 & 1,425 & 4,698 & 100 & 6,223 & 1,261 & 4,176 & 88 & 5,525 \\
\hline Buses & 798 & 0 & 0 & 798 & 742 & 0 & o & 742 & 632 & 0 & o & 632 \\
\hline Vans & 600 & 392 & 0 & 993 & 577 & 351 & 0 & 927 & 511 & 310 & o & 821 \\
\hline Trucks/lorries & 2,566 & 0 & 0 & 2,566 & 2,371 & 0 & 0 & 2,371 & 2,054 & 0 & 0 & 2,054 \\
\hline Snowmobiles & 0 & 38 & 0 & 38 & 0 & 34 & o & 34 & 0 & 30 & 0 & 30 \\
\hline ATV \& 4-whl. & 0 & 93 & 0 & 93 & 0 & 85 & 0 & 85 & 0 & 75 & 0 & 75 \\
\hline Total & 5,434 & 5,696 & 109 & 11,239 & 5,115 & 5,168 & 100 & 10,383 & 4,457 & 4,592 & 88 & 9,137 \\
\hline
\end{tabular}

As can be seen from the table, more than half of the energy consumed by land/road transport vehicles in 2016 is estimated to be consumed by cars, followed by trucks/lorries consuming almost one-fourth of the energy consumed by land/road transport vehicles in 2016. Further, it is seen that energy consumption by conventional 
vehicles is projected to decline from approximately $11.2 \mathrm{PJ}$ in 2016 to $10.4 \mathrm{PJ}$ in 2020 and $9.1 \mathrm{PJ}$ in 2035 .

Today, there is a small proportion of cars being powered by biogas. Over time this consumption is expected to fall due to two factors. The energy efficiency of gas powered cars is expected to increase slightly, and the price of electric vehicles is expected to fall more than gas powered vehicles.

The associated projected carbon-emissions will decline from approximately 755 thousand tonnes $\mathrm{CO}_{2}$ in 2020 to approximately 664 thousand tonnes $\mathrm{CO}_{2}$ in 2035 , as shown below in Table 8.

Table 8: Projected $\mathrm{CO}_{2}$-Emissions by land transport [th. tonnes $\mathrm{CO}_{2}$ ], Iceland

\begin{tabular}{|c|c|c|c|c|c|c|c|c|}
\hline \multirow{2}{*}{ [th. ton. $\mathrm{CO}_{2}$ ] } & \multicolumn{4}{|c|}{2020} & \multicolumn{4}{|c|}{2035} \\
\hline & DSL & GSL & BGS & Total & DSL & GSL & BGS & Total \\
\hline Cars & 105 & 342 & 0 & 447 & 93 & 304 & 0 & 397 \\
\hline Buses & 55 & 0 & 0 & 55 & 47 & 0 & 0 & 47 \\
\hline Vans & 43 & 26 & 0 & 68 & 38 & 23 & 0 & 60 \\
\hline Trucks/lorries & 175 & 0 & 0 & 175 & 152 & 0 & 0 & 152 \\
\hline Snowmobiles & 0 & 2 & 0 & 2 & o & 2 & 0 & 2 \\
\hline ATV \& 4-whl. & 0 & 6 & 0 & 6 & 0 & 5 & 0 & 5 \\
\hline Total & 379 & 376 & 0 & 755 & 330 & 334 & 0 & 664 \\
\hline
\end{tabular}

The above-mentioned projected $\mathrm{CO}_{2}$ emissions also represent the emissions reduction potential from conventional land/road transport in Iceland, assuming that emissionsfree vehicles can replace the entire fleet of conventional vehicles.

\section{Estimated costs of obtaining emissions reduction potential}

Estimates of the associated costs of obtaining the above-mentioned emissions reduction potential are reported below in Table 9.

Table 9: Projected total yearly vehicle costs incl. fuels [m. EUR], Iceland

\begin{tabular}{|c|c|c|c|c|c|c|}
\hline \multirow{2}{*}{ [m. EUR] } & \multicolumn{3}{|c|}{2020} & \multicolumn{3}{|c|}{2035} \\
\hline & Conv. & Altern. & Diff. & Conv. & Altern. & Diff. \\
\hline Cars & 758 & 942 & 184 & 771 & 756 & -15 \\
\hline Buses & 161 & 293 & 132 & 163 & 202 & 39 \\
\hline Vans & 95 & 116 & 21 & 97 & 93 & -4 \\
\hline Trucks/lorries & 589 & 599 & 9 & 594 & 446 & -148 \\
\hline Snowmobiles & 9 & 14 & 5 & 9 & 11 & 2 \\
\hline ATV \& 4-whl. & 35 & 51 & 16 & 36 & 40 & 5 \\
\hline Total & 1,648 & 2,015 & 367 & 1,670 & 1,548 & -122 \\
\hline
\end{tabular}

Note: Abbreviations: Conv. $=$ Projected total yearly vehicle costs incl. fuels [m. EUR], Iceland. Altern. $=$ Alternative fuel vehicles.

Diff. = Difference between conventional and alternative fuel vehicles. 
Based on expected costs and cost development it appears that annual extra costs associated with replacement of the entire fleet of conventional vehicles with emissionsfree vehicles in Iceland would amount to almost EUR 370 million in 2020, corresponding to a $\mathrm{CO}_{2}$ reduction cost of EUR 487 per tonnes $\mathrm{CO}_{2}$.

Very remarkable though is that in 2035 there will apparently not be any extra costs associated with replacement of vehicles but rather a socio-economic gain amounting to approximately EUR 120 million, corresponding to a $\mathrm{CO}_{2}$ reduction cost of EUR -184 per tonnes $\mathrm{CO}_{2}$. It is mainly trucks and lorries that cause this socio-economic gain.

This reflects - as shown by the above Table 9 - that annual costs of conventional vehicles are projected to increase slightly over the period of 2020 to 2035, primarily caused by a projected increase in prices of conventional fuels. At the same time, assumed rapid technological development of emissions-free vehicles will mean significantly decreasing vehicle costs (in combination with quite low electricity prices, and thus hydrogen, in Iceland in particular).

\subsubsection{The Faroe Islands}

Based on the overall segmentation of conventional vehicles according to vehicle type, and assumptions regarding the distribution of vehicles according to fuel type, we estimate the number of land/road transport vehicles for the Faroe Islands according to vehicle type and type of fuel as shown below in Table 10.

Table 10: Number of vehicles according to vehicle type and fuel, Faroe Islands

\begin{tabular}{lrrrr} 
Vehicle type & Diesel oil & Motor spirit & Biogas & Total \\
& DSL & GSL & BGS & \\
\hline Cars & 11,147 & 11,147 & 0 & 22,293 \\
\hline Buses & 211 & 0 & 0 & 211 \\
Vans & 3,317 & 369 & 0 & 3,685 \\
\hline Trucks/lorries & 562 & 0 & 0 & 562 \\
\hline Snowmobiles & 0 & 0 & 0 & 0 \\
ATV \& 4-whl. & 0 & 2,546 & 0 & 2,546 \\
\hline Total & 15,236 & 14,061 & 0 & 29,297 \\
\hline
\end{tabular}

\section{Energy consumption and related emissions}

As before, we then estimate the current and projected energy consumption by land/road transport according to vehicle type and type of fuel on the Faroe Islands shown below in Table 11. 
Table 11: Current and projected energy consumption by land transport [TJ], the Faroe Islands

\begin{tabular}{|c|c|c|c|c|c|c|c|c|c|c|c|c|}
\hline \multirow{2}{*}{ [TJ] } & \multicolumn{4}{|c|}{2016} & \multicolumn{4}{|c|}{2020} & \multicolumn{4}{|c|}{2035} \\
\hline & DSL & GSL & BGS & Total & DSL & GSL & BGS & Total & DSL & GSL & BGS & Total \\
\hline Cars & 364 & 413 & o & 777 & 353 & 375 & o & 728 & 312 & 333 & o & 645 \\
\hline Buses & 92 & $\circ$ & 0 & 92 & 85 & o & 0 & 85 & 73 & o & o & 73 \\
\hline Vans & 171 & 25 & 0 & 196 & 164 & 22 & o & 187 & 146 & 20 & o & 165 \\
\hline Trucks/lorries & 203 & o & 0 & 203 & 188 & o & 0 & 188 & 163 & o & 0 & 163 \\
\hline Snowmobiles & 0 & o & o & o & o & o & 0 & 0 & 0 & o & 0 & o \\
\hline ATV \& 4-whl. & 0 & 13 & 0 & 13 & o & 11 & 0 & 11 & 0 & 10 & 0 & 10 \\
\hline Total & 830 & 450 & 0 & 1,280 & 790 & 408 & 0 & 1,199 & 693 & 363 & 0 & 1,056 \\
\hline
\end{tabular}

In the Faroe Islands, also more than half of the energy consumed by land/road transport vehicles in 2016 is estimated to be consumed by cars. Trucks/lorries together with vans account for almost one-third of the energy consumed by land/road transport vehicles in 2016. Further, it can be seen from the table, that energy consumption by conventional vehicles is projected to decline from approximately $1.3 \mathrm{PJ}$ in 2016 to approximately $1.2 \mathrm{PJ}$ in 2020 and below $1.1 \mathrm{PJ}$ in 2035.

The associated projected carbon-emissions from land transport will decline from almost 90 thousand tonnes $\mathrm{CO}_{2}$ in 2020 to almost 80 thousand tonnes $\mathrm{CO}_{2}$ in 2035 , as shown below in Table 12.

Table 12: Projected $\mathrm{CO}_{2}$ emissions by land transport [th. tonnes $\mathrm{CO}_{2}$ ], the Faroe Islands

\begin{tabular}{|c|c|c|c|c|c|c|c|c|}
\hline \multirow{2}{*}{ [th. ton. $\mathrm{CO}_{2}$ ] } & \multicolumn{4}{|c|}{2020} & \multicolumn{4}{|c|}{2035} \\
\hline & DSL & GSL & BGS & Total & DSL & GSL & BGS & Total \\
\hline Cars & 26 & 27 & 0 & 53 & 23 & 24 & o & 47 \\
\hline Buses & 6 & 0 & 0 & 6 & 5 & 0 & 0 & 5 \\
\hline Vans & 12 & 2 & 0 & 14 & 11 & 1 & 0 & 12 \\
\hline Trucks/lorries & 14 & 0 & 0 & 14 & 12 & 0 & 0 & 12 \\
\hline Snowmobiles & o & 0 & 0 & 0 & 0 & 0 & 0 & o \\
\hline ATV \& 4-whl. & o & 1 & 0 & 1 & 0 & 1 & 0 & 1 \\
\hline Total & 58 & 30 & 0 & 88 & 51 & 26 & 0 & 78 \\
\hline
\end{tabular}

\section{Estimated costs of obtaining emissions reduction potential}

Estimates of the associated costs of obtaining the above-mentioned emissions reduction potential in the Faroe Islands are reported below in Table 13. 
Table 13: Projected total yearly vehicle costs incl. fuels [m. EUR], the Faroe Islands

$\begin{array}{cccccc} & 2020 & & 2035 & \\ \text { [m. EUR] } & \text { Conv. } & \text { Altern. } & \text { Diff. } & \text { Conv. } & \text { Altern. }\end{array}$ Diff.

\begin{tabular}{lrrrrrr} 
Cars & 73 & 96 & 24 & 74 & 77 & 3 \\
\hline Buses & 12 & 22 & 10 & 12 & 16 & 3 \\
\hline Vans & 15 & 20 & 5 & 15 & 16 & 1 \\
Trucks/lorries & 30 & 34 & 4 & 31 & 25 & -5 \\
\hline Snowmobiles & 0 & 0 & 0 & 0 & 0 & 0 \\
ATV \& 4-whl. & 5 & 7 & 2 & 5 & 5 & 1 \\
\hline Total & 134 & 179 & 45 & 137 & 140 & 3 \\
\hline
\end{tabular}

Note: Abbreviations: Conv. = Conventional fuel vehicles.

Altern. = Alternative fuel vehicles.

Diff. = Difference between conventional and alternative fuel vehicles.

Based on expected costs and cost development it is estimated that annual extra socioeconomic costs associated with replacement of the entire fleet of conventional vehicles in the Faroe Islands would amount to approximately EUR 45 million in 2020 and decline to around EUR 3 million in 2035.

This corresponds to a $\mathrm{CO}_{2}$ reduction cost of EUR 509 per tonnes $\mathrm{CO}_{2}$ in 2020 declining to EUR 35 per tonnes $\mathrm{CO}_{2}$ in 2035

\subsubsection{Greenland}

Following the same methodology as explained above, we estimate for Greenland the number of land/road transport vehicles according to vehicle type and type of fuel as shown below in Table 14.

Table 14: Number of vehicles according to vehicle type and fuel, Greenland

\begin{tabular}{lrrrr} 
& Diesel oil & Motor spirit & Biogas & Total \\
& DSL & GSL & BGS & \\
\hline Cars & 1,094 & 3,281 & 0 & 4,375 \\
\hline Buses & 76 & 0 & 0 & 76 \\
\hline Vans & 248 & 745 & 0 & 993 \\
\hline Trucks/lorries & 322 & 0 & 0 & 322 \\
\hline Snowmobiles & 0 & 1.179 & 0 & 1,179 \\
\hline ATV \& 4-whl. & 0 & 209 & 0 & 209 \\
\hline Total & 1,740 & 5,414 & 0 & 7,154 \\
\hline
\end{tabular}

\section{Energy consumption and related emissions}

Again, we estimate the current and projected energy consumption by land/road transport according to vehicle type and type of fuel in Greenland. These estimates are shown below in Table 15. 
Table 15: Current and projected energy consumption by land transport [TJ], Greenland

\begin{tabular}{|c|c|c|c|c|c|c|c|c|c|c|c|c|}
\hline \multirow[b]{2}{*}[\mathrm{TJ}]{} & \multicolumn{4}{|c|}{2016} & \multicolumn{4}{|c|}{2020} & \multicolumn{4}{|c|}{2035} \\
\hline & DSL & GSL & BGS & Total & DSL & GSL & BGS & Total & DSL & GSL & BGS & Total \\
\hline Cars & 45 & 184 & 0 & 229 & 44 & 167 & 0 & 211 & 39 & 149 & 0 & 187 \\
\hline Buses & 42 & 0 & 0 & 42 & 39 & 0 & 0 & 39 & 33 & 0 & 0 & 33 \\
\hline Vans & 16 & 76 & 0 & 92 & 16 & 68 & 0 & 84 & 14 & 60 & 0 & 74 \\
\hline Trucks/lorries & 147 & 0 & 0 & 147 & 136 & 0 & 0 & 136 & 118 & 0 & 0 & 118 \\
\hline Snowmobiles & 0 & 13 & 0 & 13 & 0 & 12 & 0 & 12 & 0 & 11 & 0 & 11 \\
\hline ATV \& 4-whl. & 0 & 2 & 0 & 2 & 0 & 1 & 0 & 1 & 0 & 1 & 0 & 1 \\
\hline Total & 250 & 275 & 0 & 525 & 234 & 249 & 0 & 483 & 203 & 221 & 0 & 424 \\
\hline
\end{tabular}

In Greenland, cars have a less dominate share of energy consumed by land/road transport vehicles in 2016 than in Iceland and the Faroe Islands. However, cars still consume around $45 \%$, while trucks/lorries consume around $30 \%$ and vans consume almost $20 \%$ of the energy consumed by land/road transport vehicles in 2016 . Energy consumption by conventional vehicles is projected to decline from $525 \mathrm{TJ}$ in 2016 to just above $480 \mathrm{TJ}$ in 2020 and around $425 \mathrm{TJ}$ in 2035.

The associated projected carbon-emissions will decline from approximately 35 thousand tonnes $\mathrm{CO}_{2}$ in 2020 to approximately 31 thousand tonnes $\mathrm{CO}_{2}$ in 2035 , as shown below in Table 16.

Table 16: Projected $\mathrm{CO}_{2}$ emissions by land transport [th. tonnes $\mathrm{CO}_{2}$ ], Greenland

\begin{tabular}{|c|c|c|c|c|c|c|c|c|}
\hline \multirow{2}{*}{ [th. ton. $\mathrm{CO}_{2}$ ] } & \multicolumn{4}{|c|}{2020} & \multicolumn{4}{|c|}{2035} \\
\hline & DSL & GSL & BGS & Total & DSL & GSL & BGS & Total \\
\hline Cars & 3 & 12 & 0 & 15 & 3 & 11 & 0 & 14 \\
\hline Buses & 3 & 0 & 0 & 3 & 2 & 0 & 0 & 2 \\
\hline Vans & 1 & 5 & o & 6 & 1 & 4 & 0 & 5 \\
\hline Trucks/lorries & 10 & 0 & 0 & 10 & 9 & 0 & 0 & 9 \\
\hline Snowmobiles & 0 & 1 & o & 1 & 0 & 1 & 0 & 1 \\
\hline ATV \& 4-whl. & 0 & 0 & 0 & 0 & 0 & 0 & 0 & 0 \\
\hline Total & 17 & 18 & 0 & 35 & 15 & 16 & 0 & 31 \\
\hline
\end{tabular}

\section{Estimated costs of obtaining emissions reduction potential}

Estimates of the associated costs of obtaining the above-mentioned emissions reduction potential in Greenland are reported below in Table 17. 
Table 17: Projected total yearly vehicle costs incl. fuels [m. EUR], Greenland

\begin{tabular}{|c|c|c|c|c|c|c|}
\hline \multirow{2}{*}{ [m. EUR] } & \multicolumn{3}{|c|}{2020} & \multicolumn{3}{|c|}{2035} \\
\hline & Conv. & Altern. & Diff. & Conv. & Altern. & Diff. \\
\hline
\end{tabular}

\begin{tabular}{lrrrrrr} 
Cars & 14 & 23 & 9 & 14 & 18 & 4 \\
Buses & 4 & 9 & 4 & 4 & 6 & 2 \\
Vans & 4 & 7 & 3 & 4 & 5 & 1 \\
Trucks/lorries & 17 & 24 & 7 & 18 & 18 & 0 \\
Snowmobiles & 2 & 3 & 1 & 2 & 3 & 1 \\
ATV \& 4-whl. & 0 & 1 & 0 & 0 & 0 & 0 \\
Total & 42 & 66 & 24 & 43 & 51 & 8 \\
\hline
\end{tabular}

Note: Abbreviations: Conv. $=$ Conventional fuel vehicles .

Altern. = Alternative fuel vehicles.

Diff. $=$ Difference between conventional and alternative fuel vehicles.

Annual socio-economic extra costs associated with replacement of the entire fleet of conventional vehicles in Greenland in 2020 are estimated to amount to around EUR 24 million and decline to approximately EUR 8 million in 2035.

Corresponding $\mathrm{CO}_{2}$ reduction costs are EUR 682 per tonnes $\mathrm{CO}_{2}$ in 2020 declining to EUR 266 per tonnes $\mathrm{CO}_{2}$ in 2035. These relatively higher $\mathrm{CO}_{2}$ reduction costs, particularly in 2035, reflect to some extent that electricity prices are relatively high in Greenland compared to Iceland and, to some degree, the Faroe Islands.

\subsubsection{Svalbard}

For Svalbard, we estimate the number of land/road transport vehicles according to vehicle type and type of fuel, shown below in Table 18.

Table 18: Number of vehicles according to vehicle type and fuel, Svalbard

\begin{tabular}{lrrrr} 
& Diesel oil & Motor spirit & Biogas & Total \\
& DSL & GSL & BGS \\
\hline Cars & 299 & & & \\
Buses & 0 & 455 & 0 & 754 \\
Vans & 0 & 0 & 0 & 0 \\
Trucks/lorries & 0 & 0 & 0 & 0 \\
Snowmobiles & 0 & 1,355 & 0 & 1,355 \\
ATV \& 4-whl. & 0 & 0 & 0 & 0 \\
Total & 299 & 1,810 & 0 & 2,109 \\
\hline
\end{tabular}

\section{Energy consumption and related emissions}

Estimates of current and projected energy consumption from land/road transport according to vehicle type and type of fuel in Svalbard are shown below in Table 19. 
Table 19: Current and projected energy consumption by land transport [TJ], Svalbard

\begin{tabular}{|c|c|c|c|c|c|c|c|c|c|c|c|c|}
\hline \multirow[b]{2}{*}{ [TJ] } & \multicolumn{4}{|c|}{2016} & \multicolumn{4}{|c|}{2020} & \multicolumn{4}{|c|}{2035} \\
\hline & DSL & GSL & BGS & Total & DSL & GSL & BGS & Total & DSL & GSL & BGS & Total \\
\hline
\end{tabular}

\begin{tabular}{lrrrrrrrrrrrr} 
Cars & 11 & 40 & 0 & 51 & 10 & 36 & 0 & 47 & 9 & 32 & 0 & 41 \\
Buses & 0 & 0 & 0 & 0 & 0 & 0 & 0 & 0 & 0 & 0 & 0 & 0 \\
Vans & 0 & 0 & 0 & 0 & 0 & 0 & 0 & 0 & 0 & 0 & 0 & 0 \\
Trucks/lorries & 0 & 0 & 0 & 0 & 0 & 0 & 0 & 0 & 0 & 0 & 0 & 0 \\
Snowmobiles & 0 & 24 & 0 & 24 & 0 & 21 & 0 & 21 & 0 & 19 & 0 & 19 \\
ATV \& 4-whl. & 0 & 0 & 0 & 0 & 0 & 0 & 0 & 0 & 0 & 0 & 0 & 0 \\
Total & 11 & 64 & 0 & 74 & 10 & 58 & 0 & 68 & 9 & 51 & 0 & 60 \\
\hline
\end{tabular}

In Svalbard land/road transport vehicles are basically cars and snowmobiles.

Thus cars are estimated to consume less than $70 \%$ of the energy consumed by land/road transport vehicles in 2016, while snowmobiles consequently consume around $30 \%$. Energy consumption by conventional vehicles is projected to decline from $74 \mathrm{TJ}$ in 2016 to almost $70 \mathrm{TJ}$ in 2020 and around 6o TJ in 2035.

The associated projected carbon emissions will decline from approximately 5 thousand tonnes $\mathrm{CO}_{2}$ in 2020 to approximately 4.5 thousand tonnes $\mathrm{CO}_{2}$ in 2035 , as shown below in Table 20.

Table 20: Projected $\mathrm{CO}_{2}$ emissions by land transport [th. tonnes $\mathrm{CO}_{2}$ ], Svalbard

\begin{tabular}{|c|c|c|c|c|c|c|c|c|}
\hline \multirow{2}{*}{ [th. ton. $\mathrm{CO}_{2}$ ] } & \multicolumn{4}{|c|}{2020} & \multicolumn{4}{|c|}{2035} \\
\hline & DSL & GSL & BGS & Total & DSL & GSL & BGS & Total \\
\hline Cars & 0.8 & 2.7 & 0.0 & 3.4 & 0.7 & 2.4 & 0.0 & 3.0 \\
\hline Buses & 0.0 & 0.0 & 0.0 & 0.0 & 0.0 & 0.0 & 0.0 & 0.0 \\
\hline Vans & 0.0 & 0.0 & 0.0 & 0.0 & 0.0 & 0.0 & 0.0 & 0.0 \\
\hline Trucks/lorries & 0.0 & 0.0 & 0.0 & 0.0 & 0.0 & 0.0 & 0.0 & 0.0 \\
\hline Snowmobiles & 0.0 & 1.6 & 0.0 & 1.6 & 0.0 & 1.4 & 0.0 & 1.4 \\
\hline ATV \& 4-whl. & 0.0 & 0.0 & 0.0 & 0.0 & 0.0 & 0.0 & 0.0 & 0.0 \\
\hline Total & 0.8 & 4.2 & 0.0 & 5.0 & 0.7 & 3.7 & 0.0 & 4.4 \\
\hline
\end{tabular}

\section{Estimated costs of obtaining emissions reduction potential}

In Table 21 below, the estimated annual extra costs associated with replacement of the entire fleet of conventional vehicles in Svalbard are reported. Thus, the annual extra costs are estimated to amount to approximately EUR 1.4 million in 2020 and decline to just around EUR o million in 2035 (to be more precise EUR 0.044 million). 
Table 21: Projected total yearly vehicle costs incl. fuels [m. EUR], Svalbard

\begin{tabular}{|c|c|c|c|c|c|}
\hline \multirow[b]{2}{*}{ [m. EUR] } & \multicolumn{3}{|c|}{2020} & \multicolumn{2}{|c|}{2035} \\
\hline & Conv. & Altern. & Diff. & Conv. & Altern. \\
\hline
\end{tabular}

\begin{tabular}{lllllll} 
Cars & 2.4 & 2.8 & 0.3 & 2.5 & 2.2 & -0.3 \\
\hline Buses & 0.0 & 0.0 & 0.0 & 0.0 & 0.0 & 0.0 \\
\hline Vans & 0.0 & 0.0 & 0.0 & 0.0 & 0.0 & 0.0 \\
\hline Trucks/lorries & 0.0 & 0.0 & 0.0 & 0.0 & 0.0 & 0.0 \\
Snowmobiles & 2.4 & 3.5 & 1.1 & 2.4 & 2.7 & 0.3 \\
ATV \& 4-whl. & 0.0 & 0.0 & 0.0 & 0.0 & 0.0 & 0.0 \\
Total & 4.8 & 6.2 & 1.4 & 4.9 & 4.9 & 0.0 \\
\hline
\end{tabular}

Note: Abbreviations: Conv. = Conventional fuel vehicles.

Altern. = Alternative fuel vehicles.

Diff. = Difference between conventional and alternative fuel vehicles.

However, corresponding $\mathrm{CO}_{2}$ reduction costs are EUR 285 per tonnes $\mathrm{CO}_{2}$ in 2020 declining to only EUR 10 per tonnes $\mathrm{CO}_{2}$ in 2035 .

\subsubsection{Summing up on reduction potential and costs}

In Table 21 we have summed up the projected $\mathrm{CO}_{2}$ emissions by land transport in 2020 as well as 2035 for the four regions considered.

As cars make up the vast majority of vehicles they unsurprisingly account for the majority of projected $\mathrm{CO}_{2}$ emissions - approximately $59 \%$ of emissions in 2020 as well as 2035 for all four regions considered together.

However, trucks/lorries account for a relatively high share of projected $\mathrm{CO}_{2}$ emissions, not least compared to their share of the number of vehicles, as they account for a relatively high share of energy consumption. Thus, trucks/lorries account for almost $23 \%$ of emissions, compared to $3-4 \%$ of the number of vehicles.

These findings seem to be quite general for almost all four regions considered (though to a lesser degree regarding Svalbard), although numbers of course are heavily influenced by Iceland as the one region with the absolute largest consumption of energy by land transport and thus the largest current and projected $\mathrm{CO}_{2}$ emissions and reductions potential.

Table 22: Projected $\mathrm{CO}_{2}$ emissions by land transport [th. tonnes $\mathrm{CO}_{2}$ ] reduction potential

\begin{tabular}{|c|c|c|c|c|c|c|c|c|c|c|}
\hline \multirow{2}{*}{ [th. ton. $\mathrm{CO}_{2}$ ] } & \multicolumn{4}{|c|}{2020} & & \multicolumn{5}{|c|}{2035} \\
\hline & Iceland & $\begin{array}{r}\text { Faroe } \\
\text { Islands }\end{array}$ & Greenland & Svalbard & Total & Iceland & $\begin{array}{r}\text { Faroe } \\
\text { Islands }\end{array}$ & Greenland & Svalbard & Total \\
\hline Cars & 447.5 & $53 \cdot 4$ & 15.4 & 3.4 & 519.7 & $397 \cdot 3$ & 47.4 & 13.7 & 3.0 & 461.4 \\
\hline Buses & 54.9 & 6.3 & 2.9 & 0.0 & 64.1 & 46.7 & $5 \cdot 4$ & 2.4 & 0.0 & 54.6 \\
\hline Snowmobiles & 2.5 & 0.0 & 0.9 & 1.6 & 4.9 & 2.2 & 0.0 & 0.8 & 1.4 & 4.4 \\
\hline ATV \& 4-whl. & 6.2 & 0.8 & 0.1 & 0.0 & 7.1 & $5 \cdot 5$ & 0.7 & 0.1 & 0.0 & 6.3 \\
\hline Total & 754.7 & 88.2 & $35 \cdot 4$ & 5.0 & 8833 & 664.1 & $77 \cdot 7$ & 31.1 & 4.4 & 777.4 \\
\hline
\end{tabular}


As previously indicated, the above-mentioned projected $\mathrm{CO}_{2}$ emissions also represent the emissions reduction potential from conventional land/road transport in Iceland, assuming that emissions-free vehicles can replace the entire fleet of conventional vehicles.

In Table 23 below we have summed-up the projected yearly extra vehicle costs including fuel costs for emissions free alternative fuel vehicles. These extra costs are calculated assuming that emissions-free vehicles can replace the entire fleet of conventional vehicles.

Table 23: Projected yearly extra vehicle costs for alternative fuel vehicles [m. EUR]

\begin{tabular}{|c|c|c|c|c|c|c|c|c|c|c|}
\hline [m. EUR] & Iceland & $\begin{array}{l}\text { Faroe } \\
\text { Islands }\end{array}$ & Greenland & Svalbard & Total & Iceland & $\begin{array}{r}\text { Faroe } \\
\text { Islands }\end{array}$ & Greenland & Svalbard & Total \\
\hline Cars & 184.4 & 23.8 & 8.9 & 0.3 & 217.4 & $-15 \cdot 3$ & $3 \cdot 3$ & 4.1 & -0.3 & -8.2 \\
\hline Buses & 131.8 & 10.3 & 4.4 & 0.0 & 146.5 & 39.0 & 3.4 & 1.8 & 0.0 & 44.1 \\
\hline Snowmobiles & 4.6 & 0.0 & 1.2 & 1.1 & 6.9 & 1.5 & 0.0 & 0.5 & 0.3 & 2.4 \\
\hline ATV \& 4-whl. & 16.0 & 2.2 & 0.2 & 0.0 & 18.3 & 4.7 & 0.7 & 0.1 & 0.0 & 5.5 \\
\hline Total & 367.2 & 44.9 & 24.2 & 1.4 & 437.8 & -122.1 & 2.7 & 8.3 & 0.0 & -111.0 \\
\hline
\end{tabular}

The most remarkable finding here seems to be that the projected extra socioeconomic costs of replacing conventional trucks/lorries with emissions free alternative fuel trucks/lorries are surprisingly low in 2020 already, and even more remarkably seems to represent a socioeconomic gain in 2035. As can be seen this is driven to a large degree by projected possible developments in Iceland. The two main drivers here are apparently a rapid decline in technology costs for emissions free alternative fuels trucks/lorries, especially fuel cell driven trucks/lorries, together with relatively low electricity costs and thus relatively low hydrogen fuel costs in Iceland in particular.

Table in Table 24 we have summed up the associated $\mathrm{CO}_{2}$ emissions reductions costs for the four regions considered.

Table 24: $\mathrm{CO}_{2}$ reduction cost $\left[\mathrm{EUR} / \mathrm{t} \mathrm{CO}_{2}\right]$

\begin{tabular}{lrr} 
& 2020 & 2035 \\
\hline$\left[E U R / t \mathrm{CO}_{2}\right]$ & & -183.8 \\
\hline Iceland & 486.6 & 35.0 \\
Faroe Islands & 509.2 & 266.1 \\
Greenland & 682.4 & 9.9 \\
Svalbard & 285.0 & -142.8 \\
\hline Total & 495.6 & \\
\hline
\end{tabular}





\section{Case 2: Igaliku hybrid system}

Igaliku is a settlement in southern Greenland with about 23 inhabitants. ${ }^{30}$ The annual electricity consumption of the settlement is around $170,000 \mathrm{kWh}$, equal to burning around 55,000 litres of diesel oil.

In July 2017, the energy company Nukissiorfiit launched the Igaliku hybrid project, which has the objective of finding an alternative energy source to supply electricity to Greenland's settlements. The objective of this pilot project is that a hybrid system will provide green energy to the settlement for at least half of the year. Diesel generators will continue to supply electricity during the winter months. Such a hybrid system is the first demonstration project of its kind in Greenland and aims to make Greenland greener, identify new clean energy technological opportunities and solutions, and create value by bringing knowledge and different expertise together. Nukissiorfiit aims to closely follow the project over the next years and build on its experience, possibly for the establishment of similar hybrid systems in Arctic conditions. Therefore, performance data from the system is presently studied and analysed by Nukissiorfit.

Figure 1: Igaliku Hybrid System

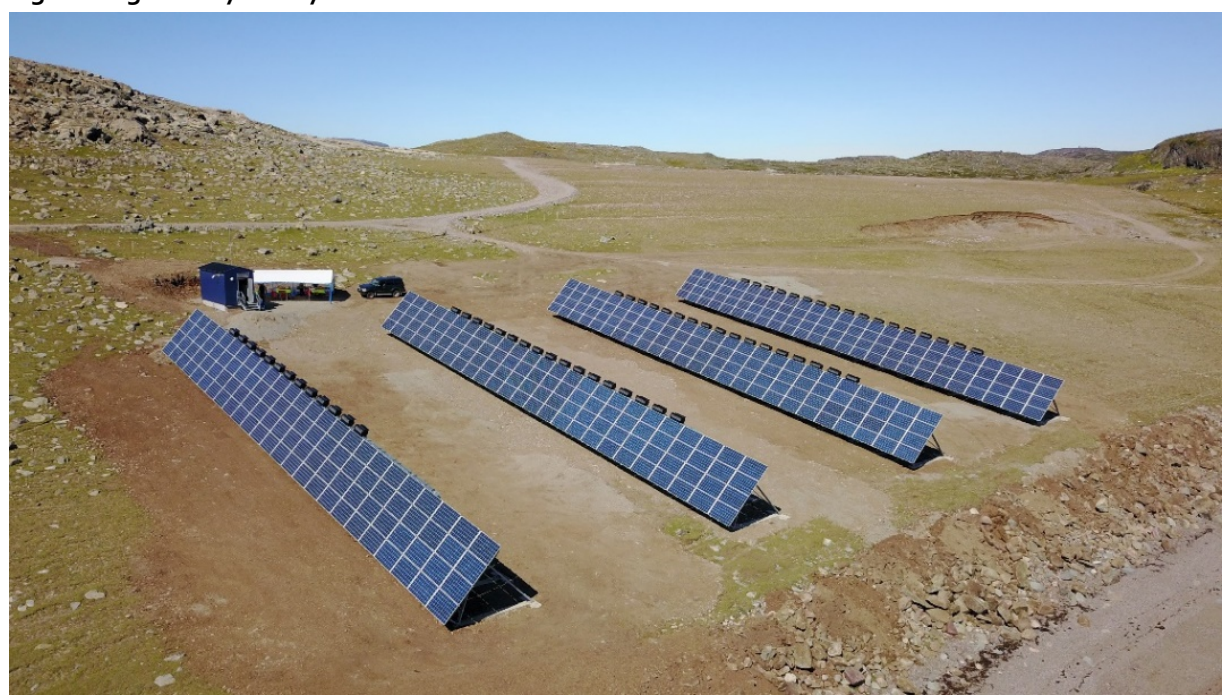

Source: Nukissiorfiit.

${ }^{30}$ Igaliku's population has decreased from 55 residents (in 2010) to 23 (in 2017) according to statistics data. 


\subsection{Hybrid systems in the Arctic}

The Igaliku hybrid project has the ambition to reduce the use of fossil fuels (diesel) by producing energy through a combination of wind and solar resources. The pilot project tests the interaction between four key components in Arctic conditions - solar panels, wind turbines, a battery bank and a diesel generator.

The Igaliku hybrid energy system consists of $620 \mathrm{~m}^{2}$ solar panels (set on a 1,400 $\mathrm{m}^{2}$ area) complemented with 68 horizontal wind turbines, which are fitted on top of the solar panels. In addition, a battery bank stores the energy produced from the solar panels and wind turbines. When there is no sufficient energy produced from the sun or wind or in the battery bank, a diesel generator supplies the settlement with energy to cover the demand.

Some of the key technical specifications are summarised in the table below.

Table 25: Key technical specifications for the Igaliku hybrid project

\begin{tabular}{|c|c|c|c|}
\hline Component & Number & Capacity & Additional info \\
\hline Solar panels & 400 & $100 \mathrm{~kW}$ & $\begin{array}{l}\text { Divided into four sections ( } 25 \mathrm{~kW} \text { each) and most active during early } \\
\text { spring to late autumn. A } 50 \text {-degree tilt ensures optimal operation under } \\
\text { the Arctic conditions. }\end{array}$ \\
\hline Wind turbines & 68 & $20 \mathrm{~kW}$ & $\begin{array}{l}\text { On top of the solar panels and most active during early autumn to the } \\
\text { spring. }\end{array}$ \\
\hline Battery bank & 1 & $190 \mathrm{kWh}$ & $\begin{array}{l}350 \text { lead acid batteries ( } \mathrm{Pb} \text {-acid) with a full capacity of } 278 \mathrm{kWh} \text { (not } \\
\text { designed for a full discharge). }\end{array}$ \\
\hline Diesel generator & 2 & $128 \mathrm{~kW}$ & Two generators ( $64 \mathrm{~kW}$ each). \\
\hline
\end{tabular}

Harsh weather conditions make the construction and operation of the system challenging. For example, powerful storms occur regularly in areas with such climate, so the solar panels had to be secured with a solid foundation consisting of 68 concrete blocks ( 4.6 tonnes each). Steel frames are attached to the concrete blocks to support the solar panels and wind turbines. Another challenge is that all constructions must be carried out during the summer months, as during the winter the days are short and the soil freezes. Also, all material was transported to the site by ship which is not possible during winter due to frozen fjords.

Initial calculations foresee that the system will save around 36,000 litres of diesel annually (corresponding to approximately DKK 200,000 with 2017 prices).

More specific energy, economic and financial data from the Igaliku hybrid system is not yet available, as the system is still in the commissioning process. ${ }^{31}$

Furthermore, there are various technological opportunities for remote and scarcely populated settlements in Greenland and the Arctic area, which could be further exploited.

\footnotetext{
${ }^{31}$ Data has been requested from Nukissiorfiit. However, the project has not yet been handed over from the contractor, which limits the availability of valid data. Data for the technologies implemented has been delivered from Nukissiorfiit for this project.
} 
For example, falling costs make the lithium ion (Li-ion) batteries more and more attractive. Li-ion is well suited to flattening out variations in energy output from seconds to hours, performs predictably over a large number of charge and discharge cycles, and has a technical life of +10 years. In addition, the battery's high energy density combined with the low weight means a relatively small and lightweight package, providing close to $1 \mathrm{MWh}$ of energy in a single six-metre container with a power capability of up to $2 \mathrm{MW}$. Containers can also be shipped fully assembled and factory tested, thus minimizing the work that has to be performed on-site, which is one of the challenges in the Arctic area.

Some companies have already designed battery containers with a "cold temperature package" that combines advanced insulation material with a hydronic heating coil.

\section{Figure 2: Energy storage Li-ion battery designed for Arctic conditions}

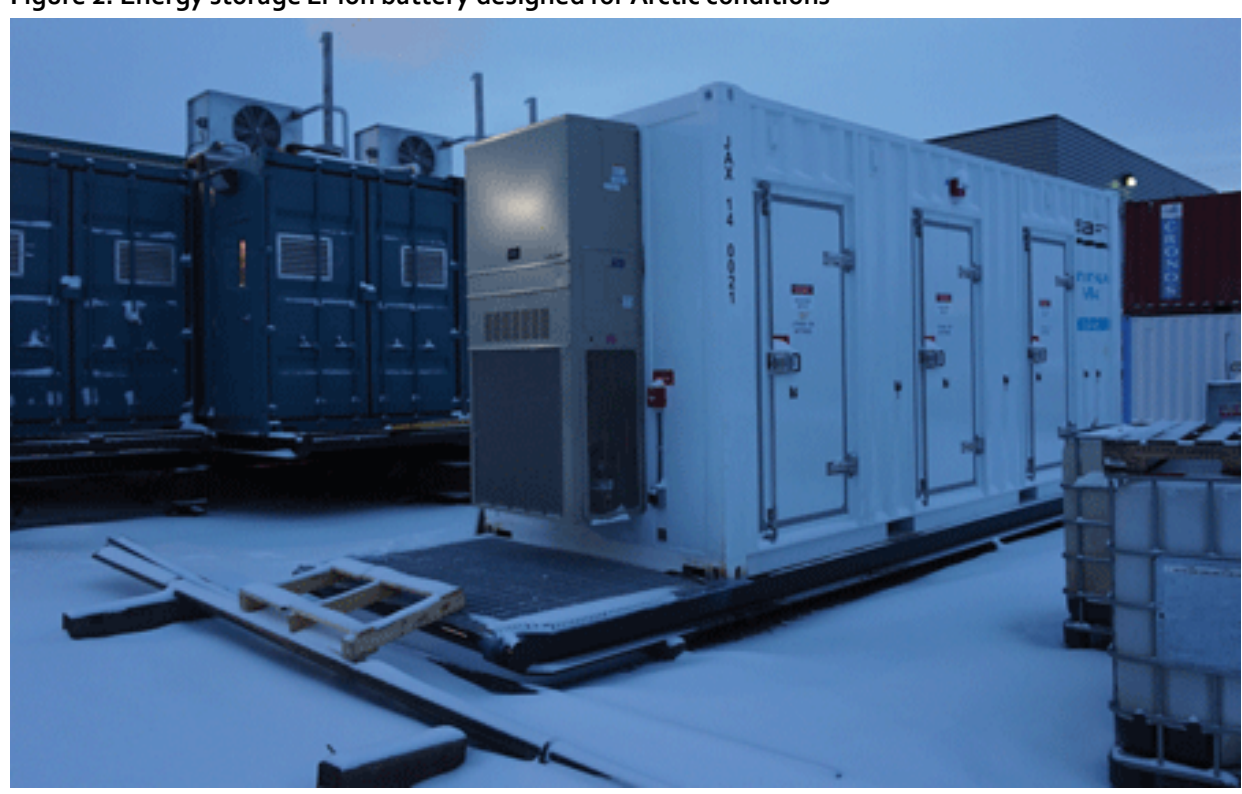

Source: Saft.

\subsection{Segmentation and potential for new technology}

There are other areas in the Arctic, which share similar characteristics as Igaliku (e.g. a micro grid system, fossil fuel dependent, Arctic climate and sparsely populated). If proven successful, the hybrid system model from Igaliku could be replicated across the Arctic. A few examples of potential settlements outside Greenland with similar characteristics are summarised below. 
Table 26: Areas in the Arctic with similar characteristics as Igaliku

Sachs Harbour, Northwest Territories, Canada

$71^{\circ} 59^{\prime} \mathrm{N}$

$88^{\circ} 11^{\prime} \mathrm{N}$

$82^{\circ} 28^{\prime} \mathrm{N}$

Alert, Ellesmere Island, Nunavut, Canada

Ny-Ålesund, Svalbard, Norway

Furthermore, according to 2017 data from Greenland's Statistics ${ }^{32,} 33$ there are 7,356 inhabitants living in settlements in Greenland. The table below presents an overview of where those settlements are located geographically (which has an impact on the weather conditions and feasibility of RE technologies), as well as the number of residents (which has an impact on the amount of energy needed to be supplied).

Table 27: Settlements in Greenland

\begin{tabular}{|c|c|c|c|c|}
\hline $\begin{array}{l}\text { Settlements } \\
\text { in/with }\end{array}$ & $\begin{array}{l}5-50 \\
\text { residents }\end{array}$ & $\begin{array}{l}50-100 \\
\text { residents }\end{array}$ & $\begin{array}{l}101-200 \\
\text { residents }\end{array}$ & $201-500$ residents \\
\hline $\begin{array}{l}\text { South } \\
\text { Greenland }\end{array}$ & $\begin{array}{l}\text { Tasiusaq (48), } \\
\text { Ammassivik (32), } \\
\text { Saarloq (28), } \\
\text { Qassimiut (24), } \\
\text { Igaliku (23), } \\
\text { Qassiarsuk (35) }\end{array}$ & $\begin{array}{l}\text { Aappilattoq (107), } \\
\text { Narsaq Kujalleq (84), } \\
\text { Eqalugaarsuit (69), } \\
\text { Arsuk (83), } \\
\text { Kapisillit (64), } \\
\text { Isortoq (74), } \\
\text { Itilleq (71) }\end{array}$ & $\begin{array}{l}\text { Narsarsuaq (139), } \\
\text { Qeqertarsuatsiaat } \\
(184)\end{array}$ & $\begin{array}{l}\text { Alluitsup Paa (240), } \\
\text { Sermiligaaq (203), } \\
\text { Kulusuk (234) }\end{array}$ \\
\hline $\begin{array}{l}\text { Central } \\
\text { Greenland }\end{array}$ & $\begin{array}{l}\text { Oqaatsut (37), } \\
\text { Kangerluk (23), } \\
\text { Niaqornat (38), } \\
\text { Ikerasaarsuk (5) }\end{array}$ & $\begin{array}{l}\text { Tiniteqilaaq (100), } \\
\text { Napasoq (71), } \\
\text { Iginniarfik (73), } \\
\text { Akunnaaq (88), } \\
\text { Kitsissuarsuit (59), } \\
\text { Ikamiut (56), } \\
\text { Ilimanaq (54), } \\
\text { Illorsuit (67) }\end{array}$ & $\begin{array}{l}\text { Atammik (193), } \\
\text { Sarfannguit (118), } \\
\text { Attu (202), } \\
\text { Ikerasaarsuk (104), } \\
\text { Qeqertaq (108), } \\
\text { Saqqaq (154), } \\
\text { Qaarsut (171), } \\
\text { Ukkusissat (149), } \\
\text { Nuugaatsiaq (102), } \\
\text { Upernavik Kujalleq } \\
\text { (195), } \\
\text { Kangersuatsiaq (157) }\end{array}$ & $\begin{array}{l}\text { Kuummiut (290), } \\
\text { Kangaamiut (318), } \\
\text { Kangerlussuaq (493), } \\
\text { Niaqornaarsuk (267), } \\
\text { Ikerasak (214), } \\
\text { Saattut (240) }\end{array}$ \\
\hline $\begin{array}{l}\text { North } \\
\text { Greenland }\end{array}$ & $\begin{array}{l}\text { Nutaarmiut (38), } \\
\text { Siorapaluk (42), } \\
\text { Qeqertat (28) }\end{array}$ & $\begin{array}{l}\text { Naajaat (54), } \\
\text { Savissivik (62) }\end{array}$ & $\begin{array}{l}\text { Aappilattoq (163), } \\
\text { Nuussuaq (189), } \\
\text { Innaarsuit (166) }\end{array}$ & $\begin{array}{l}\text { Tasiusaq (267), } \\
\text { Kullorsuaq (459) }\end{array}$ \\
\hline
\end{tabular}

${ }^{2}$ http://www.stat.gl/publ/kl/GF/2017/pdf/Greenland\%2oin\%2oFigures\%202017.pdf 33 http://bank.stat.gl/pxweb/da/Greenland/Greenland_BE_BE01_BE0120/BEXST4.PX/?rxid=bda73178-5f85-4ec4-989e9402 c8bcfgd 1 


\subsection{Potential for reductions in carbon emissions}

Some of the settlements described above could be supplied by green electricity and save between $50-60 \%$ of their annual current diesel consumption. That would make them less dependent on imports and could save up to 4.9 million litres of diesel oil per year, while also reducing the $\mathrm{CO}_{2}$ emissions from such settlements by half.

If the Igaliku system is found to be feasible, and with an acceptable security of supply, this system could be copied to similar settlements. To put this in perspective an extrapolation is listed in the table below. The table indicates the number of units and capacity if the Igaliku system were to be introduced in all the 57 village towns in Greenland listed in the table above.

Table 28: Number of unites and their capacity if the Igaliku hybrid energy system was introduced in all 57 village towns in Greenland

\begin{tabular}{lrr} 
Component & Number & Capacity \\
\hline Solar panels & 53,500 & $13,400 \mathrm{~kW}$ \\
Wind turbines & 9,100 & $2,700 \mathrm{~kW}$ \\
\hline Battery bank & $60-100$ & $25,400 \mathrm{~kW}$ \\
\hline Diesel generator & $\sim 100-200$ & $17,100 \mathrm{~kW}$ \\
\hline
\end{tabular}

It is here assumed that each settlement needs 1-2 battery banks and 2-4 diesel generators dependant of the size of the village town.

The wind turbines used in Igaliku are quite small and if established in settlements larger than Igaliku it could be relevant to expand the size of each wind turbine. In the example above the Igaliku wind turbine is used for all settlements. 



\section{Case 3: Electrification of fishing vessels}

Reducing carbon emissions from sea transport and fishing is potentially an even greater challenge than land transport. The Arctic region relies heavily on sea transport for trade and passenger transport and fishing is one of the largest contributors to economic growth in the region.

Electrification of fishing vessels could have the potential to reduce $\mathrm{CO}_{2}$ emissions considerably. This case study takes a deeper look into the potential for electrification of fishing vessels and assesses the possibilities for $\mathrm{CO}_{2}$ reduction whilst outlining the challenges for implementation.

Though this case study deals specifically with the potential and effects of electrification on the carbon emissions of the fishing fleet, it is worth noting that there are many other methods by which large carbon savings can be achieved in the sector. Policy decisions have done much to reduce the total carbon emissions, for example the quota system reduces waste and increases total efficiency per kilo catch. By protecting the fish stocks, quota systems also make the fishing more effective and therefore less energy intensive per kilo catch.

Improvements in the efficiency of machinery and equipment can also lead to large carbon savings, for example, an estimated $85 \%$ of the energy used during trawling is due to friction from the nets, ${ }^{34}$ so any improvements in nets that reduces friction will result in significant carbon savings.

\subsection{Current and upcoming technologies}

There has been a good deal of research and development with regards to efficiency and reduction of $\mathrm{CO}_{2}$ emissions in shipping, and electric ferries now operate on several commercial routes. Whilst there are different challenges related specifically to fishing vessels, some of the technologies developed for ferry transport can be applied to fishing vessels.

Siemens has been at the forefront of developments in electric shipping, with several development programmes primarily focussed on Scandinavia, and especially Finland and Norway, where there is a largely $\mathrm{CO}_{2}$ neutral electricity supply from hydropower. ${ }^{35}$ Status and progress are summarised below:

\footnotetext{
34 http://www.nordicenergy.org/wp-content/uploads/2016/04/Nordic-Energy-Technology-Perspectives-2016.pdf

35 https://www.siemens.com/press/en/feature/2015/corporate/2015-05-e-ferry.php
} 


\subsubsection{Electric ferries}

There are several commercial ferry routes sailing electric ferries developed by Siemens. These typically operate on short routes with battery charging at each port during loading and unloading. Most notably, Siemens has developed a zero emission ferry, named MF Ampere, which sails $6 \mathrm{~km}$ in 20 minutes carrying up to 120 vehicles and 360 passengers. The ferry has been in operation since March 2015 and is located in the western part of Norway, sailing between Lavik and Oppedal. ${ }^{36}$

The Elektra ferry started operation in June 2017 and carries up to go cars and 370 passengers between Nauvo and Parainen in the Turku archipelago in Finland. The crossing is 15 minutes long, and the Elektra's two batteries (with a capacity of $530 \mathrm{kWh}$ each) can be charged in five minutes whilst loading and unloading. ${ }^{37}$

Siemens plans to put two more ferries into operation in January 2018, which will cover the E39 Anda-Lote route on the west coast of Norway. They will sail a $2.4 \mathrm{~km}$ route, and can carry 120 cars and 349 passengers each..$^{38}$

\section{Fishing industry}

Siemens has further developed the technology used on electric ferries for the markets of fish farming and fishing vessels with the development of a fully electric service boat for fish farming (Elfrida), and a hybrid fishing vessel (Karoline).

The Elfrida has been in operation since February 2017, and is used to transport feed and equipment, repair and relocate fish cages, check anchorages and make repairs and inspections. It travels to the fish hatchery, $12 \mathrm{~km}$ from the coast, once a day; the trip takes approximately 50 minutes. One hundred percent battery operation is possible for a working day of 8 hours. ${ }^{39}$

The Karoline is a hybrid fishing vessel designed for trips of 8-12 hours and developed by Siemens and Selfa Artic AS. It has a diesel generator set for emergencies and batteries, which are recharged overnight whilst in port. The Karoline can use batteries for most of its power requirements, resulting in an $80 \%$ reduction in the overall diesel consumption. The Karoline has been in operation since October 2015. During its first 30 days of service, it caught approximately $58,000 \mathrm{~kg}$ of fish, but consumed only 0.04 litres of diesel per $\mathrm{kg}$ of fish, a reduction of $80 \% .4^{\circ}$

Those working on the Karoline report that the working environment is less strenuous than a traditional fishing vessel due to the lack of noise, fumes and vibration from the diesel engine.

An added benefit of electric fishing vessels in very cold climates is that they can be fitted with an efficient heating system for use when in harbour. During cold weather, fishing vessels need to be heated all the time they are in port to prevent freezing. A diesel motor used for heating is inefficient and expensive and heats the surrounding

\footnotetext{
${ }^{36}$ https://www.siemens.com/press/en/feature/2015/corporate/2015-05-e-ferry.php

${ }_{37}$ https://www.siemens.com/press/en/feature/2015/corporate/2015-05-e-ferry.php

$3^{8}$ https://www.siemens.com/press/IG2017030032COEN

39 https://www.siemens.com/press/PR2017020187PDEN

$4^{\circ}$ https://www.siemens.com/press/pool/de/feature/2015/corporate/2015-05-e-ferry/media-service-anchors-aweigh-e.pdf
} 
water as well as the boat. Electrical heating can be connected directly to shore power and, as well as being more efficient, prevent local pollution from diesel engines.

Another benefit is an estimated decrease in maintenance costs, as electric driven motors need less maintenance than diesel motors.

Electrical power for the fishing industry is in the early stages of development, but is an area that is expected to grow in the future as technology is proven and cost is reduced. Selfa Arctic AS has a great deal of experience with fishing vessels in cold climates and operates two ship yards in Trondhiem and Rødskjær, Norway, providing repair and service to fishing vessels as well as boat construction. Selfa Arctic worked with Siemens on the development of the Karoline, and Company Director Erik lanssen is clear on the potential for electrically powered shipping fleets. In December 2015, during development of the Karoline, lanssen remarked that "In five years' time, we will see battery-driven fishing boats as completely normal"..$^{11}$

We contacted Erik lanssen to discuss the potential for electric fishing vessels and to hear his views on the future, and he remains positive that electrification is the future of fishing vessels. lanssen commented that the technology is available now for short range fishing vessels and he expects that this will develop to include longer range vessels in the near future.

Erik lanssen is very optimistic about electrification of boats and ferries in general and reports that besides the electric ferries already in operation in Norway, 53 fully electric ferries are under construction. His expectation is that hybrid battery-fuel cells will also play a significant part in improving efficiency of shipping within the next five years.

Besides electrification of fishing vessels described above, it is also interesting to consider hydrogen fuel cell ship propulsion in the fishing industry. Hydrogen has many interesting benefits in terms of energy storage and it goes well with wind and solar power.

To date, development projects using fuel cells for propulsion are focussed on ferries and cruises. Viking Cruises aims at introducing fuel cell technology and build the world's first cruise ship fuelled with hydrogen. Earlier in 2017, Royal Caribbean Cruises announced that they were developing cruise ships fully powered by LNG fuel cells, due to be operational in 2022 and 2024. They also stated that fuel cell technology was to be trialled on an existing ship and progressively test larger fuel cell projects..$^{42}$

There are still many challenges related to the use of hydrogen fuel cell technology for ship propulsion. The storing system on the ship requires an even tougher handling and storage systems at sea than LNG. It has a high investment cost and the power requirements and dynamic response requirements at sea can also be challenging. 43

\footnotetext{
$4^{1}$ https://www.siemens.com/press/pool/de/feature/2015/corporate/2015-05-e-ferry/media-service-anchors-aweigh-e.pdf

42 https://maritime-executive.com/article/worlds-first-hydrogen-powered-cruise-ship-scheduled

43 http://www.motorship.com/news101/fuels-and-oils/cutting-through-the-hydrogen-hype
} 


\subsection{Categorisation and potential for new technology}

The technology available for electric propulsion of fishing vessels is currently limited to shorter-range trips. Because of these limits, it is sensible to categorise shipping vessels according to range of activity to allow assessment of potential $\mathrm{CO}_{2}$ savings.

As a starting point, an assessment of the fishing fleets in the areas was made, a number of references were used to assist. First it was found that, in general, the majority of fishing vessels use a type of distillate fuel as marine diesel oil, and only a minority run on heavy fuel oil, most of which are larger vessels. ${ }^{44}$ Second, for the scenario analysis, the main project data was collected for each location. The data consolidated the point that the majority of fuel for fisheries is either diesel oil, kerosene or motor spirit accounting for $76 \%$ of fuel, and heavy fuel oil accounting for the other $24 \%$ (based on an average on data for the Faroe Islands, Greenland and Iceland).

Based on the information above, it is reasonable to assume that all heavy oil is used by large, long-range vessels. However, the fuel consumption of small and medium sized vessels will vary greatly according to a number of factors such as species of fish, weather conditions and where they are fishing.

In terms of numbers, it can be assumed that most of the small and medium sized fishing fleet are smaller boats without heavy machinery on board. These are most likely to be out at sea for a limited time, and be in port every night.

Of the medium sized boats, some will be trawlers that operate on a daily basis, coming into harbour every night, and some will be line-fishing boats that could be out for longer.

The mix of different boat types makes categorisation very difficult. We therefore have chosen to split the fishing fleet according to fuel types to give an indication of possibilities for carbon reduction:

- Diesel oil, kerosene and motor spirit, account for an average of $76 \%$ of fuel used for fishing industry in the three locations of the Faroe Islands, Greenland and Iceland;

- Heavy fuel oil, account for $24 \%$ of fuel used for fishing industry in the three locations of the Faroe Islands, Greenland and Iceland.

Energy consumption and suitability to run on a different fuel type will depend not only on the size of vessel and how long it is out at sea, but also on the conditions under which it is operating and what species it is fishing.

44 http://www.seafish.org/media/Publications/FS27_04.09_Fuel_emissions.pdf 


\subsection{Potential for reductions in carbon emissions}

Based on the categorisation of the vessels, the total potential for electric propulsion in sea transport today and in the medium and long term has been estimated together with the reductions in carbon emissions from a transition to electric propulsion.

The overall potential of electrification of fishing vessels is evaluated with the point of departure in data collected for earlier stages of this project. Only data for fisheries of the three locations of Greenland, Iceland and the Faroes Island was obtained.

Table 29: Carbon emissions related to fisheries in the Faroe Islands, Greenland and Iceland today. Based on data for fuel consumption for fisheries collected in the main project

\begin{tabular}{lrrr}
\hline Carbon emissions, tonnes $\mathrm{CO}_{2}$ & Faroe Islands & Greenland & Iceland \\
\hline Diesel and others & & & \\
Heavy fuel oil & 170,000 & 100,000 & 454,000 \\
Total & 57,000 & 25,000 & 163,000 \\
\hline
\end{tabular}

Assuming diesel oil, kerosene and motor spirit for small and medium size vessels and heavy fuel oil for larger vessels.

Siemens estimates that in Norway the fishing fleet could reduce its fuel consumption by $80 \%$ by converting to electric propulsion, assuming a transition of smaller fishing vessels to vessels similar to the Karoline.

Another study by Siemens, NELFO, ELFO and Bellona Foundation ${ }^{45}$ estimates a fuel consumption reduction of $50 \%$ in Norway for smaller fishing vessels, taking into account the age of the fishing fleet and the investments in new and rebuilt vessels.

When assuming that $100 \%$ of the diesel-fuelled fishing industry is converted to electric fishing vessels with respectively $50 \%$ and $80 \%$ reduction of emissions as described above, the figures in the graph below show the potential for carbon emission reductions. The carbon reduction of course assumes that the electricity used to charge batteries is from a renewable source.

The graph below presents a projection of a possible long-term scenario for $\mathrm{CO}_{2}$ reduction. The projection assumes an $80 \%$ reduction in carbon emissions on all diesel fuelled fishing vessels as above. In addition, massive investments in hydrogen fuel cell propulsion (zero emission) is assumed to cover $100 \%$ of the heavy oil fuelled vessels.

\footnotetext{
45 http://network.bellona.org/content/uploads/sites/2/2017/08/Elektrifisering-av-

kystfiskeflaten.pdf?_utma $=123600408.1203258448 .1501756656 .1502784911 .1502791637 .21 \&$ _utmb $=123600408.0 .10 .15$ $02791637 \&$ \&utmc $=123600408 \&$ _utmx $=-$

\&_utmz $=123600408.1502192186 .7 .2 . u t m c s r=g o o g l e \mid u t m c c n=($ organic $)|u t m c m d=o r g a n i c| u t m c t r=($ not $\% 20$ rovided $) \& \_u t$ $\mathrm{mv}=-\&$ _utmk $=157751482$
} 




The results shown on the graph above will require different timescales for realisation and will depend on a number of factors, including: timescale for replacement and/or upgrade of fishing fleet; costs of technology; relative cost of electricity compared to fuel oil; and any possible legislation or benefits. Scenarios for short and medium range vessels will have a shorter timeframe than those for long-range vessels, as the technology is not developed enough to make a good assessment on timescales for implementation on long-range vessels.

Replacement and renewal of fishing vessels is a gradual process, with fishing fleets in the Nordic countries having an average age of around 30 years. ${ }^{46}$ Therefore, policy intervention and incentives is a critical consideration in the realisation of reduction of carbon emissions from fishing fleets.

The long-term scenario in the graph is therefore based on rough assumptions for a technology that seems not yet ready for fishing vessels or sea transport in general. The purpose is to show that a scenario exists with potentially massive carbon emission reductions, whilst acknowledging some carbon emissions and an unknown time perspective. 
Table 30: Carbon emissions per capita for the Faroe Islands, Greenland and Iceland

Today

Although data on fishing vessels in Svalbard was not significant in comparison to the other areas, it can be assumed that there is a small fishing industry based in Svalbard. As an indicator the "average" emission per capita from the table above could be used.

Jan Mayen is only occupied during summertime. Fisheries as an industry in Jan Mayen is therefore not considered for this case study. 



\section{Case 4: Tourism}

With pristine nature, the Arctic islands provide an authentic wildlife experience for tourists. But, the massive amount of tourism puts pressure on the environment, both in terms of the wildlife and the infrastructure of the destinations. In this case study we will focus on the possible economic impacts of tourism and the pressure put specifically on the energy infrastructure of four selected Arctic islands; Iceland, Greenland, the Faroe Islands and Svalbard in Norway.

\subsection{Tourism development}

\subsubsection{Growth in Arctic tourism}

The Arctic islands are experiencing a massive growth in tourism with Iceland reaching an impressive 1.8 million foreign tourists in 2016. A growth of around 175\% since 2012. Greenland, the Faroe Islands and Svalbard have experienced an increase in tourism levels as well, though at a lower level than Iceland, with a growth ranging from $15 \%$ to 45\% since 2012.

Not only are more tourists arriving at the Arctic islands, they are also spending more with the average foreign tourist visiting Iceland spending DKK 6,700 in 2016 compared to DKK 5,700 in 2012. As the duration of the visits have not increased, the increased spending is caused by a higher daily spending by the tourists. 
Figure 4: Development in tourism $2012=100$ (foreign passengers arriving by plane)

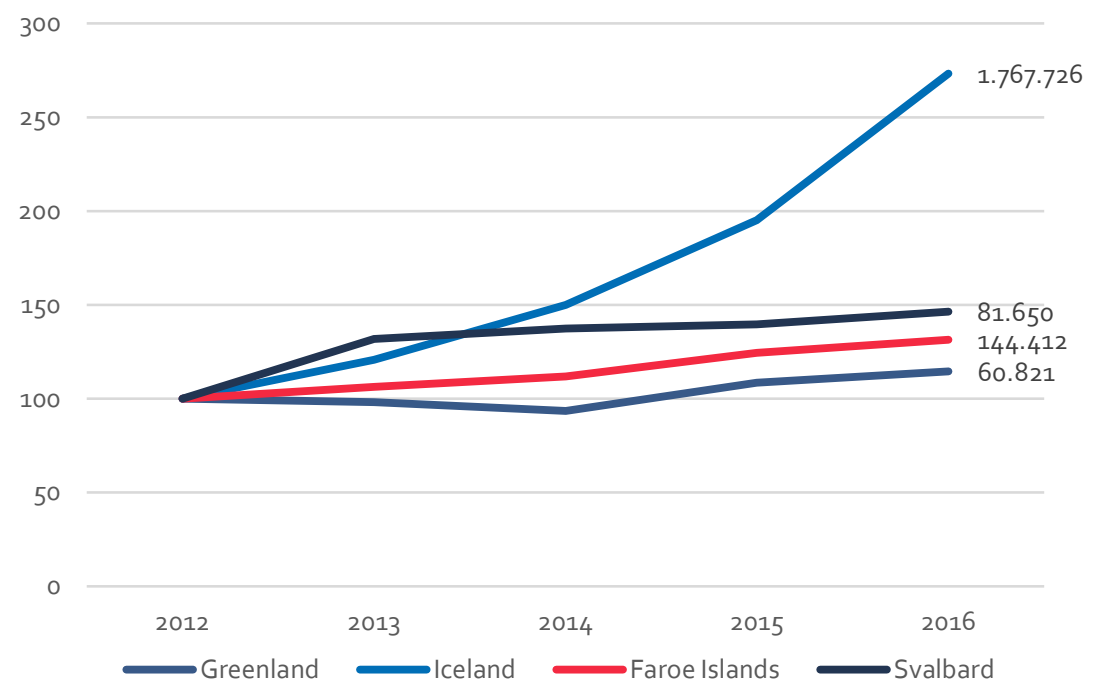

Source: Statistics Greenland (TUXFLY), Statistics Iceland (SAM02001), Statistics the Faroe Islands (SS01010), Statistics Norway for Svalbard (8508-1).

Figure 5: Revenue per foreign tourist, DKK

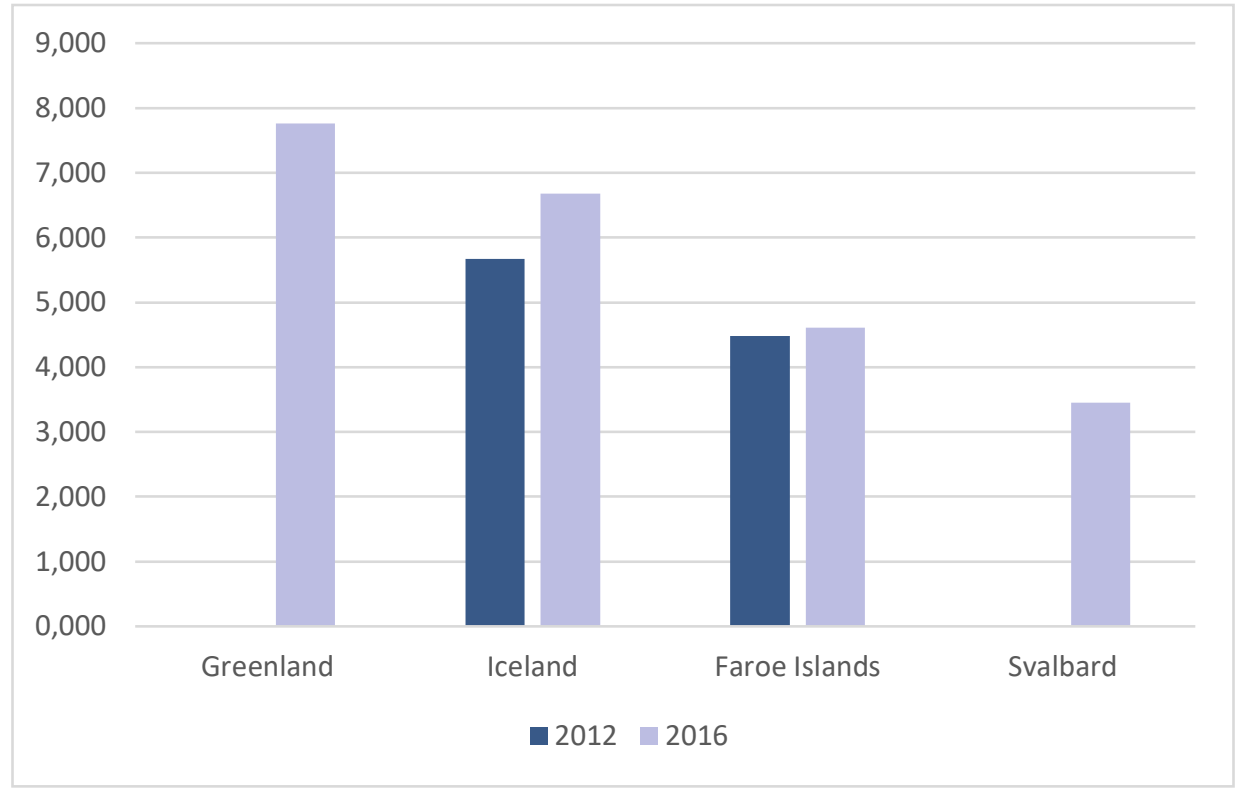

Note: Similar spending patterns is seen in spending per overnight stay.

Source: Annual reports for Visit Greenland and the Faroe Islands, Statistics Iceland (SAMo80o8), Statistics Norway for Svalbard (SSB). 
This rapid growth of tourism in the Arctic islands provides both opportunities and challenges. Tourism may create short and long-term profits and jobs for a region leading to economic growth, provided it is managed sustainably. However, the tourism may also put pressure on natural resources and infrastructure, such as the energy system and waste management.

\section{Stable revenues and indirect spending from tourism}

Tourism may provide stable revenues for the locals during the tourism season with spending on accommodation, food and beverages and cultural experiences such as angling, hunting and nature tourism. This spending of tourist creates indirect spending in local communities as the salaries paid in the tourism sector is spent across other sectors.

Capacity of infrastructure scaled to peak season and low utilization in off season A key element of a sustainable tourism industry is building, operating and maintaining tourism infrastructure such as transport facilities, law enforcement, medical and emergency services, water and waste water utilities, waste collection, and energy utilities. The capacity of these investments must be scaled, built and maintained to the number of people during peak seasons, even though these numbers are only reached a few months a year.

The increasing tourism levels therefore leads to increased energy consumption in a wide range of sectors such as transportation, accommodation and other tourism services. Most tourists visit the Arctic Islands in the summer months with 40-50\% visiting in June to August. In Greenland, more than $20 \%$ of the total annual tourism is in August alone.

Figure 6: Tourist seasonality in 2016 based on foreign arrivals and overnight stays, percentage of annual no of tourist arrivals

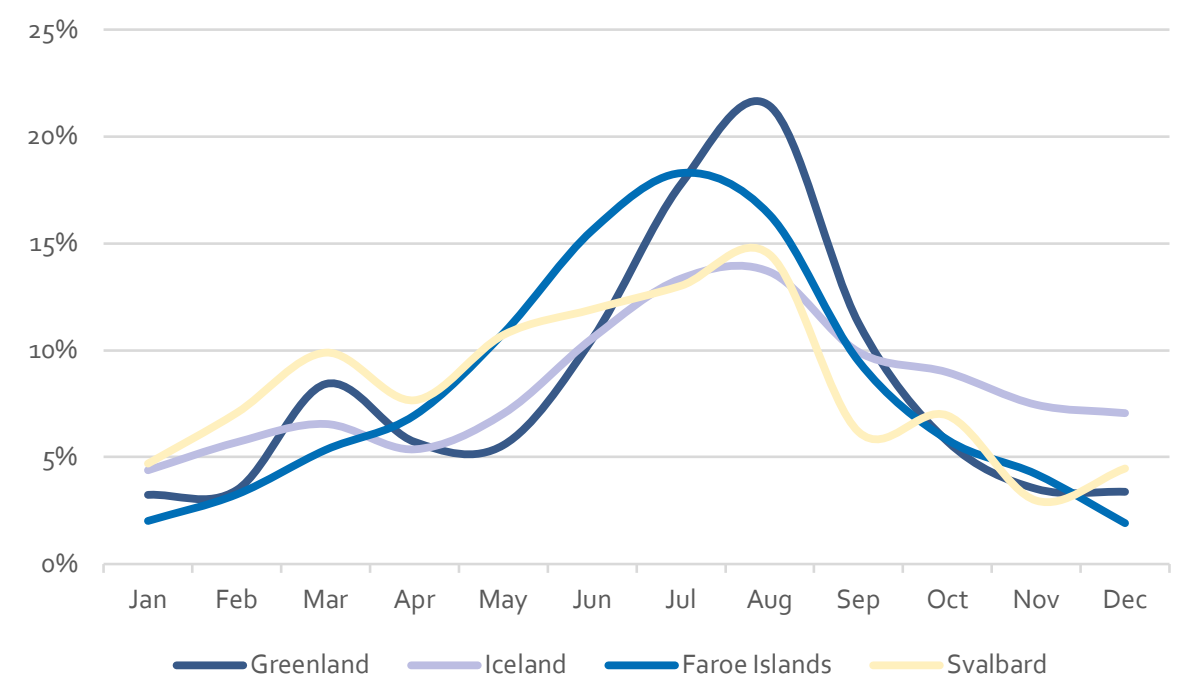

Note: For Svalbard the seasonality is based on quarterly data, why the monthly arrivals is calculated as a weighted average.

Source: Statistics Greenland (TUXFLY), Statistics Iceland (SAM02001), Statistics Faroe Islands (SS01010), Statistics Norway for Svalbard (8508-1). 
During summer, the number of tourists outnumbers the population of Svalbard more than four times. For Iceland, tourists do not outnumber the population but are close to matching them in numbers with around 240,000 arriving foreign tourists in both July and August compared to the population of 334,000 inhabitants.

In Iceland, the energy system is dimensioned to the large energy-intensive industries, so the comparatively small increase from tourism does not stress the capacities of the current infrastructure.

\subsection{Carbon emission from the tourism sector}

As highlighted in the previous section the increasing tourism levels lead to increased energy consumption and hence a higher $\mathrm{CO}_{2}$ emissions in a wide range of sectors such as transportation, accommodation and other tourism services.

Below are some examples of the level of $\mathrm{CO}_{2}$ pollution from transportation due to tourism as well as from hotels and restaurants. It has not been possible to obtain data on the level of energy consumption or the $\mathrm{CO}_{2}$ emissions from the commercial enterprises arranging activities for tourists.

\subsubsection{Air transportation}

Tourists use transportation to travel to the Artic region and for travelling around to different locations at their destinations. The investigated locations in the Artic region can only be reached by airplane or boat.

It is a well-known fact that travelling by plane is a major carbon sinner of tourism. Below, we have estimated the carbon emissions of the international tourists for the Arctic islands. With by far the highest number of tourists, Iceland also has the highest estimated carbon emissions of approximately 750,000 tonnes of $\mathrm{CO}_{2}$ equivalent.

Table 31: Estimated carbon emissions from international tourism arriving by air

\begin{tabular}{lrrrrr} 
Destination & $\begin{array}{r}\text { Arrivals by } \\
\text { plane }\end{array}$ & $\begin{array}{r}\text { Total estimated } \\
\text { tonnes } \mathrm{CO}_{2^{-}}\end{array}$ & $\begin{array}{r}\text { Estimated } \\
\text { tonnes } \mathrm{CO}_{2^{-}}^{-} \\
\text {e/tourist }\end{array}$ & $\begin{array}{r}\text { Total passenger } \\
\text { km by plane in } \\
\text { millions }\end{array}$ & $\begin{array}{r}\text { Average } \\
\text { distance in km }\end{array}$ \\
\hline Greenland & 60,821 & 40,079 & 0.66 & 275 & 4,513 \\
Iceland & $1,767,726$ & 751,786 & 0.43 & 5,149 & 2,913 \\
Faroe Islands & 144,412 & 25,409 & 0.18 & 174 & 1,205 \\
Svalbard & 81,650 & 23,679 & 0.29 & 162 & 1,986 \\
\hline
\end{tabular}

Source: Statistics Greenland (TUXFLY), Statistics Iceland (SAM02001), Statistics Faroe Islands (SS01010), Statistics Norway for Svalbard (8508-1), calculator.carbonfootprint.com

Increased fuel efficiency

In the recent years, Icelandair has made numerous operational changes towards improved fuel efficiency and thereby lower carbon footprint. They mention that all their aircrafts are fitted with 
winglets reducing fuel burn. They continuously work with winglets improvements and engine core wash equipment.

Their fuel burn per 100-revenue passenger kilometre have decreased to 3.7 litres in 2016 from 3.83 litres in 2014. A fall of $3.4 \%$.

Table 32: Increased fuel efficiency 2014-2016, Icelandair

\begin{tabular}{lrrr} 
Fuel burn & 2014 & 2015 & 2016 \\
Litres/10o-revenue passenger kilometre (RPK) & 3.83 & 3.79 & 3.7 \\
Kg/operational tonnes kilometre (OTK) & 0.296 & 0.290 & 0.283 \\
\hline
\end{tabular}

Source: Icelandair Annual report 2016.

The decrease of $4.4 \%$ in $\mathrm{kg}$ per operational tonne kilometre shows that the increased fuel efficiency is not a product of just increased revenue and capacity utilisation.

\section{Greenland}

Table 33: Estimated carbon emissions from international tourism arriving by air, Greenland

\begin{tabular}{lrrrrr} 
Nationality/market area & Defined round trip & Visitors & Share & tonne $\mathrm{CO}_{2}$-e & Estimated tonne $\mathrm{CO}_{2}$-e \\
\hline Denmark & Copenhagen-Nuuk & 28,958 & $48 \%$ & 0.52 & 15,058 \\
Other Europe & Frankfurt-Nuuk & 15,041 & $25 \%$ & 0.55 & 8,273 \\
USA and Canada & New York-Nuuk & 4,991 & $8 \%$ & 0.44 & 2,196 \\
Other & Beijing-Nuuk & 11,831 & $19 \%$ & 1.23 & 14,552 \\
Total & & 60,821 & $100 \%$ & & 40,079
\end{tabular}

Source: Statistics Greenland (TUXFLY), Visit Greenland Annual report 2016, calculator.carbonfootprint.com

Iceland

Table 34: Estimated carbon emissions from international tourism arriving by air, Iceland

\begin{tabular}{llrrrr} 
Nationality/market area & Defined round trip & Visitors & Share & tonne $\mathrm{CO}_{2}$-e & $\begin{array}{r}\text { Estimated } \\
\text { tonne } \mathrm{CO}_{2} \text {-e }\end{array}$ \\
\hline North America & New York-Reykjavik & 498,431 & $28 \%$ & 0.61 & 304,043 \\
UK & London-Reykjavik & 316,395 & $18 \%$ & 0.32 & 101,246 \\
Nordic Countries & Copenhagen-Reykjavik & 175,373 & $10 \%$ & 0.31 & 54,366 \\
Central/S-Europe & Frankfurt-Reykjavik & 356,546 & $20 \%$ & 0.35 & 124,791 \\
Other & Average & 420,981 & $24 \%$ & 0.40 & 167,340 \\
Total & & $1,767,726$ & $100 \%$ & & 751,786 \\
\hline
\end{tabular}

Source: Statistics Iceland (SAMo2001), Visit Iceland Annual report 2016, calculator.carbonfootprint.com 
The Faroe Islands

Table 35: Estimated carbon emissions from international tourism arriving by air, the Faroe Islands

\begin{tabular}{|llrrrr}
\hline Nationality/market area & Defined round trip & Visitors & Share & tonne $\mathrm{CO}_{2}$-e & $\begin{array}{r}\text { Estimated } \\
\text { tonne } \mathrm{CO}_{2} \text {-e }\end{array}$ \\
\hline Denmark & Copenhagen-Vágar & 66,742 & $46 \%$ & 0.2 & 13,348 \\
Norway & Bergen-Vágar & 15,835 & $11 \%$ & 0.1 & 1,583 \\
Germany & Berlin-Vágar & 11,029 & $8 \%$ & 0.24 & 2,647 \\
Iceland & Reykjavik-Vágar & 8,103 & $6 \%$ & 0.11 & 891 \\
Other & Average & 42,703 & $30 \%$ & 0.1625 & 6,939 \\
\hline Total & & & & 25,409 \\
\hline
\end{tabular}

Source: Statistics Faroe Islands (SS01010), Visit Faroe Islands Annual report 2016, calculator.carbonfootprint.com

\section{Svalbard}

Table 36: Estimated carbon emissions from international tourism arriving by air, Svalbard

\begin{tabular}{ll|l|l|r|r} 
Nationality/market area & Defined round trip & Visitors & Share & tonne $\mathrm{CO}_{2}$-e & $\begin{array}{r}\text { Estimated tonne } \\
\mathrm{CO}_{2} \text {-e }\end{array}$ \\
\hline Norwegian & Oslo-Longyear & 81,650 & $100 \%$ & 0.29 & 23,679 \\
\hline
\end{tabular}

Source: Statistics Norway for Svalbard (8508-1), Svalbard Annual report 2016, calculator.carbonfootprint.com

\section{Cruise ships}

Like air travel, cruise trips are a fuel-intensive form of travelling. Based on the MyClimate Cruise calculator an average passenger on a 7 days cruise causes 2.4 tonnes of $\mathrm{CO}_{2}$ equivalents when sharing a double room. Because of economies of scale regarding fuel consumption, larger cruise ships have a lower carbon footprint per passenger than smaller cruise ships.

With 104 cruise ships travelling to Greenland in 2016, the average amount of $\mathrm{CO}_{2}$ equivalents per passenger is estimated at 3.175 tonnes.

Table 37: Estimated carbon emissions from a cruise tourist

\begin{tabular}{lrrr}
\hline Cruise capacity, passengers & tonne $\mathrm{CO}_{2}$-e & No of cruise ships by capacity & Share \\
\hline & & & \\
less than 500 & 3.4 & 83 & $80 \%$ \\
\hline $500-1000$ & 2.4 & 17 & $16 \%$ \\
$1000-2000$ & 1.8 & 4 & $4 \%$ \\
$2000-3000$ & 1.5 & 0 & $0 \%$ \\
more than 3000 & 1.3 & 0 & $0 \%$ \\
Total & 3.175 & 104 & $100 \%$ \\
\hline
\end{tabular}

Note: Calculated for 1 passenger sharing a double cabin on a 7 day cruise.

Source: Visit Greenland Annual report 2016, https://c02.myclimate.org/en/cruise_calculators/new 
Using the average emissions of $\mathrm{CO}_{2}$ equivalent given the Greenlandic distribution of cruise ships, the total emission of cruise tourists of the four Arctic Islands is estimated to almost 728,000 tonnes. Based on the number of passengers and vessels the average capacity of the cruise ships to Iceland, the Faroe Islands and Svalbard must be larger and thereby obtaining economics of scale compared to the Greenlandic cruises. Therefore, if we correct the estimated carbon emissions for number of passengers per cruise ship the total emission is just above 544,000 tonnes.

We have no knowledge of the duration of the cruises across the Arctic, however it is fair to assume that the duration of cruises with port calls solely on Svalbard would be less than seven days.

Table 38: Estimated carbon emissions from cruise tourists

\begin{tabular}{lrrrr} 
Destination & Passengers & Vessels & Passenger port calls & Estimated tonne $\mathbf{C O}_{2}$-e \\
Greenland & 24,244 & 104 & 83,585 & 76,975 \\
\hline Iceland & 101,000 & 113 & 319,303 & $242,400-320,675$ \\
Faroe Islands & 63,000 & 72 & $\mathrm{NA}$ & $151,200-200,025$ \\
Svalbard & 41,000 & 30 & $\mathrm{NA}$ & $73,800-130,175$ \\
Total & & & & $544,375-727,850$ \\
\hline
\end{tabular}

Source: Annual reports for Visit Greenland, Faroe Islands, Iceland and Svalbard 2016, https://co2.myclimate.org/en/cruise_calculators/new

In the above estimate, we have not taken into account that the cruise ships may call ports in more than just the specific islands. A cruise calling ports on both Iceland and the Faroe Islands would therefore count double as they are registered as tourists in both countries.

\section{Electric and hybrid cruise ships}

Cruise ship builders and operators have in the recent years started to invest in developing hybrid and electric ships to reduce reliance on fuels like diesel and heavy fuel oil. Norwegian cruise line "Hurtigruten" is for instance investing in ships with a hybrid engine developed by Rolls Royce that aims to offer quieter sailing through tour routes in the Arctic and Antarctic. The first ship will be available in 2018 and will, according to Hurtigruten, be equipped with an auxiliary battery-powered engine that allows for near-silent sailing for up to 30 minutes. Another ship that will be delivered later will be able to cruise for longer periods of time. ${ }^{47}$

\subsubsection{Hotels and restaurants}

Hotels and hostels account for the primary energy use in the tourism sector (not taking into account air travel), using two types of energy similar to a regular household; electricity and heat. Both the electricity and heat can be purchased from the grid or produced on site depending on the location of the accommodation and the energy services provided.

\footnotetext{
47 https://qz.com/1039133/the-electric-revolution-is-coming-to-freighters-and-cruise-ships/
} 




Source: Construction 21.

An average hotel spends $35 \%$ of their energy consumption on space heating, water heating, and cooking. The remaining $65 \%$ is divided more or less evenly between office equipment, ventilation, lighting, refrigeration, and cooling.

Energy costs account for up to $10 \%$ of the operational costs and $60 \%$ of the property's carbon footprint.

The tourism sector (hotels and restaurants) of Greenland ${ }^{48}$ had an energy consumption of $104 \mathrm{TJ}$ in 2015 , where the primary source of energy was oil at $70 \%$. The high amount of oil is a result of the decentralised energy production at the hotels with generators supporting the energy supply. With 240,000 overnight stays the $\mathrm{CO}_{2}$ emission per overnight stay amounts to $28.5 \mathrm{~kg}$. In total, hotels and restaurants in Greenland account for close to 7,000 tonnes of $\mathrm{CO}_{2}$ emissions annually.

$4^{8}$ Data availability on the energy consumption in hotels and restaurants in the Arctic is low. It has only been possible to find concrete data on energy consumption from hotels and restaurants in Greenland. 
Table 39: Energy consumption and $\mathrm{CO}_{2}$ emissions from hotels and restaurants, Greenland 2015

\begin{tabular}{lrr} 
Oil & 69 & 74 \\
Electricity & 14 & 53 \\
Heat & 17 & 59 \\
Other & 4 & $\mathrm{NA}$ \\
Total & 104 & 69 \\
No of overnight stays & 240,631 & 28.5 \\
$\mathrm{CO}_{2}$-impact per overnight stay $\left(\mathrm{kg} \mathrm{CO}_{2}\right)$ & & 6,851 \\
$\mathrm{CO}_{2}$-impact of tourism (tonnes $\left.\mathrm{CO}_{2}\right)$ & & \\
\hline
\end{tabular}

Source: Statistics Greenland (ENE2FBR) and (TUXHOT).

The estimated carbon emissions from hotels and restaurants varies greatly for the Arctic islands, a variation primarily driven by the differences in the compositions of the energy supply. In Iceland, the centrally supplied electricity and heat is produced using primarily hydro and geothermal power. In Svalbard, the electricity and heat production is mainly based on coal and diesel oil.

The tourism sector can move towards a reduction of their carbon emission through energy efficiency measures or by switching their energy supply from fossil fuels to renewable energy sources. Energy efficiency measures can be implemented directly by the sector whereas a switch to renewable energy must be driven by the energy production sector if the energy is produced centrally. In the cases where the energy is not produced centrally the tourism sector can take steps towards a reduction in fossil fuels.

Construction 21, which is a social media dedicated to all professionals active in the sustainable building and city sector, lists several measures that hotels and restaurants can take to reduce their energy consumption without affecting the comfort of their guests. Among these are:

- Training staff in more energy efficient behaviour

- Reminders for the guests to turn off the lights and only put dirty towels on the floor

- Light bulbs (shifting from regular light bulbs to LED lights)

- New appliances with higher energy efficiency

- Less laundry from both staff and guests

- Booking order of rooms (book in clusters, sun-side during winter and shade side during summer in order to avoid heating and cooling, save corners and top floors for last).

Besides energy efficiency measures the hotels and restaurants of the Arctic Islands can reduce their carbon emissions by switching to renewable energy. If the energy supply is not based on renewable energy, their carbon emissions will not decrease by connecting to the grid. In these cases, decentralized energy plants can ensure a sustainable energy supply dimensioned to the specific demand of the hotel and/or restaurant. 


\subsection{Tourism as a driver for green transition}

Tourism is an important economic driver in the Artic region. In Iceland, the direct contribution from the tourism was $7 \%$ of the total GDP in 2016 and the total contribution (including indirect effects) was estimated to be $34 \%$ of GDP. 49 In the Faroe Islands the contribution from tourism was $1.4 \%$ of GDP in 2015 and the tourism industry accounted for $7.3 \%$ of all the product and service exports in $2015 .^{50}$

Besides being a benefit to the environment, investments in green initiatives in the tourist sectors can also be a benefit to the local businesses and the economy, as it can lead to a more efficient use of resources in the long term. In the short term, investments in green initiatives can nevertheless increase prices in the tourist sectors. However, recent studies conducted on tourism levels in Australia indicate positive support for renewable energy and willingness to pay extra for environmentally friendly accommodation. ${ }^{1}$

Most of the tourists who travel to the Artic region also state that one of the main reasons is to see the nature and wildlife..$^{52}$ This indicates that tourists that travel to the Artic region generally prefer nature experiences and it is therefore not unlikely that they will be willing to pay extra to preserve the nature. A case study investigating visitors' willingness to pay entrance fees to natural attractions show that modest fees would not significantly decrease the demand for these attractions. ${ }^{53}$

\subsubsection{Increasing focus on Ecotourism}

In recent years, there has been an increasing focus on the tourism impact on the environment and as a result, the focus on ecotourism has increased. There is no generally accepted definition of ecotourism, but the World Conservation Union defines Eco-tourism as "Environmentally responsible travel and visitation to relatively undisturbed natural areas, in order to enjoy and appreciate nature (and any accompanying cultural features-both past and present) that promotes conservation, has low visitor impact, and provides for beneficially active socio-economic involvement of local populations". 54

Some tourist destinations have implemented initiatives to reduce the pollution from tourism. An example of this is the winter resort complex "Aspen Snowmass" located in Colorado, USA. Aspen Snowmass has developed an energy plan and implemented a wide range of measures with the aim of cutting emissions by $10 \%$ by 2012 and $25 \%$ by 2020 . One of the most far-reaching initiatives Aspen Snowmass has taken was to ban Kimberly Clark (KC) paper products, due to the fact that the company

\footnotetext{
49 World Travel \& Tourism Council (2017), Economic impact 2017 Iceland.

$5^{\circ}$ Visit Faroe Islands (2016), Annual report 2016.

${ }^{1}$ Frantál \& Kunc (2011).

$5^{2}$ Visit Greenland (2016), Tourism statistics report 2016 and Icelandic Tourist Board (2017), Tourism in Iceland in figures.

53 Reynisdottir, Song \& agrusa (2008), Willingness to pay entrance fee to natural attractions: An Icelandic case study,

Elvisier.

54 Hector Ceballos-Lascurain (1996), Tourism, Ecotourism and Protected Areas, IUCN
} 
engaged in destructive logging practices and didn't recycle any fibre. Even though Aspen Snowmass' spending on KC product was low, the case attracted a considerable amount of media attention, and as a result, $\mathrm{KC}$ changed their fibre resourcing practices. This shows that tourist destinations can influence the sustainability in the supply chain. 55

In the Artic area, there are also examples of ecotourism/green initiatives in the tourist sectors. In the table below, are some examples of green initiatives in the Artic region.

\section{Table 40: Examples of green initiatives in the Artic region}

\begin{tabular}{|c|c|c|}
\hline Country & Initiative & Description \\
\hline \multirow[t]{3}{*}{ Iceland } & Environmental awards & $\begin{array}{l}\text { The Icelandic Tourist Board reward the tourist sector their annual Environmental } \\
\text { awards, focusing on a strong commitment to sustainability and environmental } \\
\text { consciousness. }\end{array}$ \\
\hline & $\begin{array}{l}\text { Environmental } \\
\text { certifications for } \\
\text { hotels in Iceland }\end{array}$ & $\begin{array}{l}\text { Several hotels, hostels and guest houses in Iceland hold an environmental } \\
\text { certification ensuring their guests that they will limit their environmental } \\
\text { footprint. Many of the certifications focus on reducing the carbon emissions } \\
\text { where possible as well as limiting waste, water usage etc. The accommodations of } \\
\text { Iceland hold certifications among: } \\
\text { ISO-14001 Environmental Management } \\
\text { Earth Check } \\
\text { Nordic Ecolabelling - limiting } \mathrm{CO}_{2} \text { emissions where relevant } \\
\text { Vakinn Quality (bronze, silver and gold) } \\
\text { A part of the certification is a focus on management of energy usage and } \\
\text { benchmark against other accommodations. }\end{array}$ \\
\hline & Ecotourist Iceland & $\begin{array}{l}\text { Ecotourist Iceland is a privately founded non-profit organization. Its purpose is to } \\
\text { promote eco-friendly tourism in Iceland and gather all the various eco-friendly } \\
\text { companies in the tourist industry in one place to make it easy for the traveller to } \\
\text { choose the environmentally friendly choice. } .^{6}\end{array}$ \\
\hline Greenland & Hotel Artic in Ilulissat & $\begin{array}{l}\text { A hotel that focus on reducing their impact on the environment by investing in } \\
\text { green technology and training. } 57 \\
\text { Awarded with the Green Key since } 2000 \text {. }\end{array}$ \\
\hline
\end{tabular}

55 Gossling (2011), Carbon Management in Tourism - Mitigating the impacts on climate change.

${ }^{6} \mathrm{http}: / /$ www.ecotourist.is/how-we-work

$57 \mathrm{http}: / /$ hotelarctic.com/csr/groent_miljoe/ 



\section{Case 5: De-carbonizing Svalbard}

Today Svalbard's energy supply comes primarily from coal extracted from the local coalmine. However, the coalmine is expected to close within 10 years, at which point an alternative has to be in place. This is a unique opportunity for Svalbard to transition to a carbon free energy supply.

Data collected during the main project show that the primary energy consumption for electricity, heat and transportation in Svalbard is approx. 247,000 MWh, of which coal accounts for almost go percent.

The focus on reducing the carbon emissions and maintaining a high level of security of energy supply was the subject of a conference in Svalbard, in June 2017. Contributors included knowledge institutions, consultancies and contractors presenting technologies and solutions for de-carbonizing Svalbard..$^{58}$

This case is based on a short objective description of each presentation from the conference followed by considerations for the given technology in a de-carbonizing perspective. The considerations are summarized in the end of the chapter for a full comparison.

In addition to presentations from the conference, a relevant study has been carried out on the future energy system in Longyearbyen by PhD candidate Hans-Kristian Ringkjøb of the University of Bergen. ${ }^{59}$ This has been reviewed and considered as part of the assessment. We have also discussed the possibilities for the future of energy supply in Svalbard with Hans-Kristian and taken his comments into account in our analysis.

After our analysis, and just before this report went into printing, the Norwegian Ministry of Petroleum and Energy published a study called "Alternativer for framtidig energiforsyning på Svalbard" ${ }^{\prime 60}$. We did not have the time to compare our analysis with the results from this study, but the reader are welcomed to compare our "Table 53: Potential Energy technologies for Svalbard" with their summary (page 80-82).

Longyearbyen already has a district heating system, and it is understood that most of the buildings in the town are connected to the network. This makes it easier to implement changes in the supply of heat energy to the end users as the heat is delivered to the place of use (as opposed to individual oil boilers, where a change of heat supply technology would require individual replacement at each building). With regards to the heat supplied to the buildings, the method by which the heat is generated is of no direct concern to residents. Therefore, heat can be supplied by a number of different methods according to the available resources at any time.

\footnotetext{
$5^{8}$ http://www.sintef.no/arrangementer/fremtidens-energiforsyning-i-longyearbyen/

59 http://www.uib.no/en/energy/113294/modelling-future-energy-system-longyearbyen-\%E2\%80\%93-hans-kristianringkj\% $3 \%$ B8b-gfi

${ }^{60}$ https://www.regjeringen.no/no/aktuelt/mulighetsstudie-for-energiforsyning-pa-svalbard/id2607092/
} 
It is therefore assumed that the existing district heating network is utilized, thus focus is put on collective energy supply solutions and not individual solutions.

The condition and operational requirements of the district heating network and the heating installations within buildings are not considered in detail in the case study. It is recommended that efficiency improvements and refurbishment of the district heating network is carried out in connection with any new heat supply project.

\subsection{Existing energy consumption in Svalbard}

The number of permanent residents in Svalbard has increased steadily over the past 25 years, and today there are around 2,100 residents. A high level of security of supply is crucial on the isolated island, and up to now energy generation using locally mined coal has provided good security of supply for the community.

In Svalbard there is a demand for heat and electricity all year around. Apart from a short period during the summer, the heat demand is higher than the electricity demand.

Figure 8: Seasonal and daily profiles of the energy demand for Svalbard (Illustration from "The future energy system in Longyearbyen - a modelling study, by Hans-Kristian Ringkjøb, PhD-Candidate Renewable Energy, Geophysical Institute, Bergen University) ${ }^{61}$

Seasonal cycle

Daily profiles



${ }^{61}$ http://www.uib.no/en/energy/113294/modelling-future-energy-system-longyearbyen-\%E2\%80\%93-hans-kristian-

ringkj\% $3 \%$ B 8 b-gfi 
Table 41: Primary energy consumption in Svalbard today. Data collected in the main part of the project Primary energy consumption per fuel MWh Share in $\%$ of total

Diesel oil (DSL) total

- Hereof electricity production

- Hereof transportation

The energy consumption data, in Table 41 and Table 32, have been collected for Svalbard in the main part of the project. The energy consumption according to fuel type is listed in Table 41, which is further separated into shares for production of electricity, heat and for transportation.

The electricity, heat and transportation demand in Svalbard are listed in Table 42.

Table 42: Energy demand for electricity, heat and transportation. Data collected in the main part of the project

\begin{tabular}{lrr} 
Demand & MWh & MWcalculated (min/max) \\
Electricity & 38,000 & $1 / 6$ \\
Heat & 68,000 & $5 / 15$ \\
Transportation & 3,7000 & - \\
\hline
\end{tabular}

\subsection{Catalogue of technical solutions for replacing fossil fuel based energy supply}

The 10-year perspective of closing the coalmine has given Svalbard a unique chance to rethink the future energy supply. In the following, presentations from the conference and from the PhD-candidate are described separately, and followed by considerations to each technology.

\subsubsection{Electrification with cable}

The presentation "Kabel til Svalbard" (Cable to Svalbard), by Tor-Eivind Moen, ABB. ${ }^{62}$ The interest in establishing a cable from Norway to Svalbard started more than 20 years ago. However, at that time the coalmine still had a very long lifetime. Now, with ten

62 http://www.sintef.no/contentassets/275dae666db8496aa5e8936379odac78/05-1206-2017_elektrifisering-avsvalbard_sintef-workshop-1.pdf 
years perspective of closing of the coal mining industry, the possibility of a cable connection to the mainland is a more realistic option.

There is also political interest in a cable that can signal efficiency and security of supply, especially if the connection is expanded to a "Barent's grid", where the Barents Sea is considered as whole.

A cable offers a high level of security of supply and is a long-term solution. But related to other alternatives of energy supply, the initial costs of a cable are high. A cost estimate in the presentation shows an initial cost from EUR 310 million to EUR 518 million. The last estimate includes redundancy.

\section{Discussion and considerations}

Technically, the cable would be a secure and stable energy supply of both heat and electricity. The heat production would, of course, require additional technologies for heat production. This could be the mature technologies of electric boilers and/or heat pumps. Combined with heat storage this could provide high security of supply all year.

The high initial costs and long maturation period should be closely assessed regarding possible changes in energy demand of Svalbard in the meantime. The relatively small energy demand of Svalbard is sensitive to changes, such as unknown growth in tourism, new industries and to some extent also growth of the city of Longyearbyen. In addition, Svalbard is still bound to coal production for a ten-year period.

Establishing a cable to Svalbard would be convenient in the attempt to reach a decarbonised scenario but the costs would be much too high compared with the energy transmitted. A local energy system with import of biofuels seems much more relevant. In addition to this there must be local capacity with fuels available for back-up at Svalbard to maintain an acceptable level of security of supply.

Table 43: Cable to Svalbard - summary

\begin{tabular}{|c|c|}
\hline \multicolumn{2}{|l|}{ Cable to Svalbard } \\
\hline Cost (per MWh or kWh) & $\begin{array}{l}\text { High initial costs } \\
\text { Transmissions costs, } 35 \mathrm{MW} \text { and } 33 \% \text { yearly utilization, between } 0.20 \text { and } 0.33 \mathrm{EUR} / \mathrm{kWh} \\
\text { This does not include investment costs or the cost of generating power, the base cost will } \\
\text { depend on where the power comes from and how it is generated (e.g. from Norway). }\end{array}$ \\
\hline Maturity of technology & $\begin{array}{l}\text { High maturity. Electric cables are used many places in Europe connecting islands to main } \\
\text { lands. }\end{array}$ \\
\hline
\end{tabular}


The presentation "Fremtidsrettet energiforsyning for Longyearbyen og Svalbard Naturgass-sol hybrid" (Future energy supply for Longyearbyen and Svalbard - Natural gas-solar hybrid), by Harald Vartdal, Seatres AS. ${ }^{63}$

At the conference, a unique modular LNG storage and fuelling facility was presented. It is installed at seabed at shallow waters of 10-25 meters, and is designed to facilitate the gradual introduction of renewable energy technologies in the energy system, e.g. solar or wind.

It was also presented that the potential for solar energy in Svalbard during summer is favourable due to low ambient temperatures and reflections from snow. If solar panels are combined with battery storage, it would nearly meet Longyear's electricity demand during summertime. This would require solar panels covering an area covering 46 ha.

The presentation states that the initial cost of solar energy has decreased by $85 \%$ since 2010, which makes solar energy favourable. Large capacity battery storage is more utilised and available.

As presented, a LNG terminal and solar panels can be established within two to three years from ordering of the facility. The technologies are described as easy accessible and well known.

This hybrid solution combines low emission with stable and secure power supply.

\section{Discussion and considerations}

Natural gas has low carbon emission compared to other fossil fuels, it can be stored over time and has good synergies with renewables such as solar energy. LNG is also suitable for marine services.

This solution will still have some carbon emissions associated, so it does not meet the requirements of decarbonisation in a single step, but it might assist with transition.

It is an advantage that the energy hybrid of LNG and renewable energy is easily adapted to fluctuations of demand during the day.

There will be a need for establishing LNG or electricity heat production capacity. This could be the mature technologies of electric boiler and/or heat pump. Combined with heat storage this could serve high security of supply all year.

Wind as alternative to solar should also be considered. There is more potential for electricity production from wind all year around, while the potential for solar power is only present during summer.

63 http://www.sintef.no/contentassets/275dae666db8496aa5e8936379odac78/o6-hv--11062017-fremtidsrettetinfrastruktur--for-longyearbyen-hybrid.pdf 
Table 44: LNG and solar hybrid - summary

LNG and solar hybrid

Cost (per MWh or kWh) Depends on the share of PV and LNG. The more PV and LNG storage, the higher the initial investment costs. If LNG is imported, this will increase running costs.

$\begin{array}{ll}\text { Maturity of technology } & \begin{array}{l}\text { Electricity production from LNG is a mature technology. } \\ \text { LNG has also been used for years in marine sector etc. } \\ \text { Solar energy is a mature technology that is continuously undergoing efficiency development. }\end{array} \\ \text { Security of supply } & \begin{array}{l}\text { Only sun during summertime. The solar power capacity must be covered by other technology } \\ \text { during winter. } \\ \text { LNG needs to be imported all year around. }\end{array}\end{array}$

\subsubsection{Hydrogen}

The presentation "Hydrogens rolle i Longyearbyens energiforsyning" (The role of hydrogen in Longyearbyen's energy supply), by Anders Ødegård and Jonas Martin, SINTEF. ${ }^{64}$ And The presentation "Nullutslipp hydrogen i bunn, energilab på toppen Mulig fremtidig energiforsyning og aktivitet for Svalbard" (Zero emission hydrogen base load, energy lab on top - Possible future energy supply and activity for Svalbard), by Per Sandberg, Statoil. ${ }^{65}$

In itself, hydrogen is a $\mathrm{CO}_{2}$ neutral energy carrier like electricity. However, contrary to electricity, hydrogen can be relatively easily stored and adapted to match the energy demand.

In the presentations, hydrogen is not produced locally and there is a need for establishing secure transportation and storage facilities. Svalbard will depend on hydrogen to be shipped, as diesel is shipped today.

It is presented that a hybrid solution consisting of hydrogen and solar energy could possibly be an alternative to the present coal based energy supply. The yearly cost of importing hydrogen in combination with local solar energy is estimated at around EUR 28 million in the presentation by Anders Ødegård.

If the energy supply consists of $100 \%$ import of hydrogen, the investment costs are estimated to be around EUR 30 million per year.

The same presentation concludes that the hydrogen-solar hybrid is the most economically feasible compared to other options such as 100\% wind, 100\% solar, and cable.

The presentation by Per Sandberg suggests that Svalbard could act as a light house and energy lab for a hydrogen supplied community based on innovative solutions with the vision of establishing the world's most efficient and green governance of an Arctic territory. Replication in other isolated islands and rural areas is possible.

\footnotetext{
64 http://www.sintef.no/contentassets/275dae666db8496aa5e8936379odac78/07-

20170612_hydrogen_svalbard_odegard_kortversjon_til-pdf.pdf

65 http://www.sintef.no/contentassets/275dae666db8496aa5e8936379odac78/08-svalbard-presentasjon-sandberg.pdf
} 


\section{Discussion and considerations}

One of the advantages using hydrogen for energy production is that it can be stored and adapted to demand, and can therefore act as base load. For this reason, hydrogen and renewables such as wind and solar energy would be a good mix.

The presentations above deal with hydrogen imported by ship. However, depending on the mix of energy technologies in Svalbard, it may be viable to produce some hydrogen locally.

Local production at this scale would require massive investment in production facilities, hereunder also electricity production facilities as wind or solar, for sufficient hydrogen production.

Instead, hydrogen could have a different role and be considered as a means to balance fluctuating electricity production from other technologies. In this case, it could be produced and stored locally. The share of hydrogen in the total energy production would, of course, be less compared to the above situation but the role as balancing power production and storage for later utilization as peak energy production is of great value in an isolated energy system.

Hydrogen could act as a transitional solution and, if produced locally, the production can be increased as wind energy is expanded.

Hydrogen can also be gradually introduced to the transport sector.

Table 45: Hydrogen - summary

Hydrogen

Cost (per MWh or kWh) Depends on level of storage and whether hydrogen is produced locally or imported.

Maturity of technology The technology is somewhat mature, all though not as mature as solar and wind.

Security of supply High security of supply. Easy adaption to demand. High synergy effect with renewables such as wind or solar energy.

The security of supply should be assessed closely if hydrogen is imported.

\subsubsection{Solar energy}

The presentation "Smart bruk av solenergi i Longyearbyen" (Smart solar energy in Longyearbyen), by Bjørn Thorud, Multiconsult. ${ }^{66}$

It is presented that $25 \%$ of Longyear's yearly energy demand can be covered by solar energy with high efficiency PV panels established on roof tops. If this is the case, there is no foreseen impact on nature.

If the PV panels are established in PV parks, it would give a higher production but also have an impact on nature. Approx. $75 \%$ of the demand can be covered. Solar energy requires a smart energy management and storage system.

${ }^{66}$ http://www.sintef.no/contentassets/275dae666db8496aa5e8936379odac78/10--130755---thorud---fremtidens-

energisystem-i-longyearbyen-publ.pdf 
The presentation states that PV panels in principle can cover 100\% demand, if there is no limit to area of the panels. In reality this is not feasible, and there is also still the fact that there is no solar energy production during winter as the graph below shows.

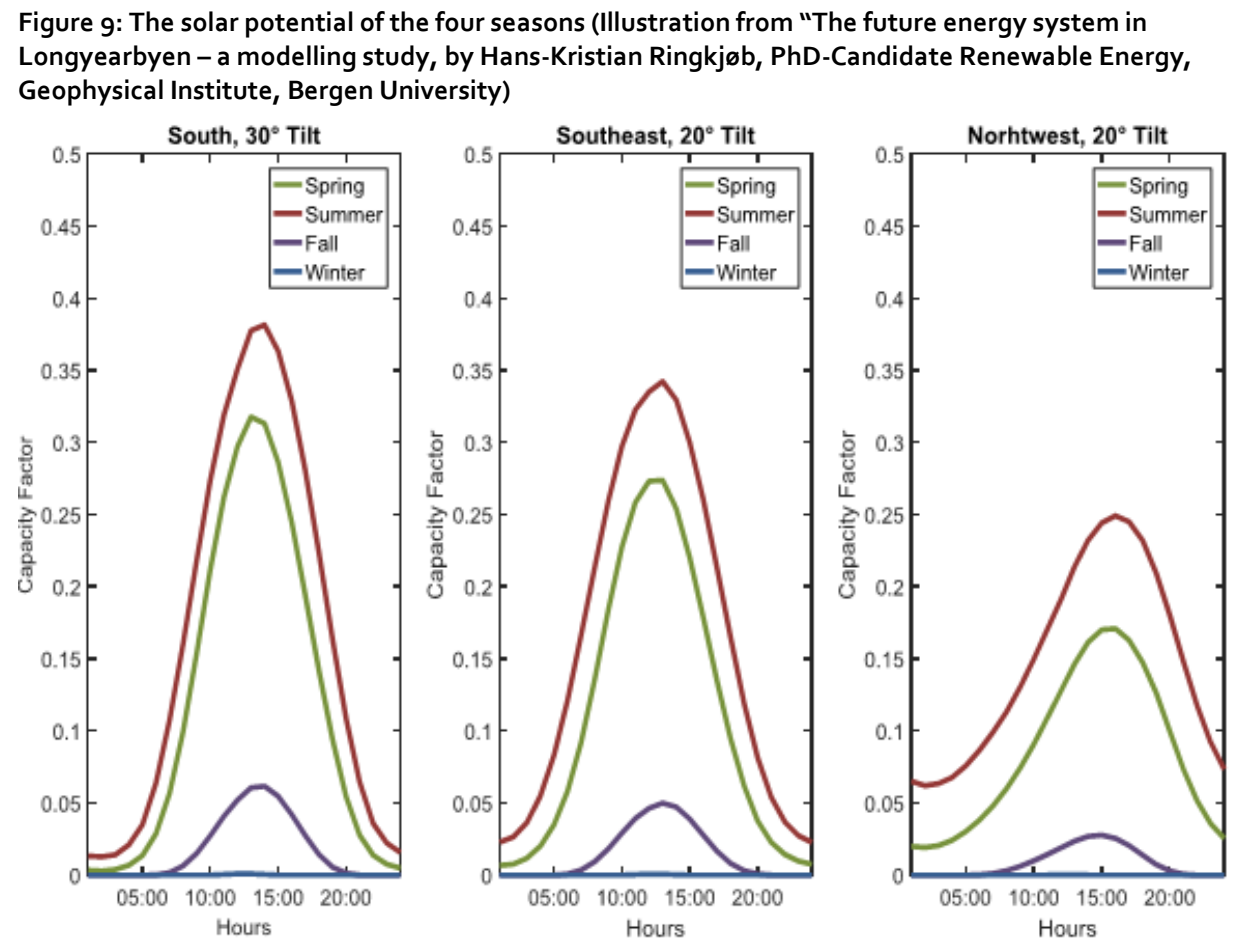

The presentation regarding hydrogen described in section 6.2.3 gives the estimated price of $100 \%$ solar energy supply to be EUR 72 million.

\section{Discussion and considerations}

For an area like Svalbard with no hydro or geothermal power present, the energy system should either be based on technologies which can be used all year, or a more complex system based on seasonal energy storage. Since solar energy is only present during summer there would therefore either be the need of additional capacity (wind power) or some seasonal storage solutions (hydrogen). With wind power in an electrified energy system (electric heating) there should not be the need for further electric capacity from PV's. If PV's should cover a significant part of the annual electricity consumption there would be a need for seasonal energy storage. Solar energy is therefore not expected to be relevant at Svalbard as a main supply technology.

As long a fossil fuels is a part of the energy system PV's could be very relevant as a way to decrease the fossil fuel consumption.

An advantage is the role as transitional supply. The transition from coal to solar energy can be started now, and gradually expanded. When solar power provides a large 
part of the electricity production during summer, the wind power capacity should be increased to supply the energy system with renewable energy during winter.

Table 46: Solar energy - summary

\section{Solar energy}

Cost (per MWh or kWh)

Relatively low costs compared with many other technologies.

Also requires investment in additional technologies for an optimal working energy system.

Maturity of technology

Very mature technology, that is continuously undergoing development.

Security of supply

Reliable technology during summer time only.

\subsubsection{Wind energy}

The presentation "The future energy system in Longyearbyen - A modelling study", by Hans-Kristian Ringkjøb, PhD-candidate, University of Bergen. ${ }^{67}$

Wind energy could provide a share of the future energy mix in Svalbard. Solar energy is available during summer, whereas wind energy has higher availability in the winter, as shown below.

Figure 10: The potential for wind energy in the four seasons (Illustration from "The future energy system in Longyearbyen - a modelling study", by Hans-Kristian Ringkjøb, PhD-Candidate Renewable Energy, Geophysical Institute, Bergen University)


${ }^{67}$ http://www.uib.no/sites/w3.uib.no/files/attachments/hans-kristian_ringkjob_o.pdf 
The referenced modelling study suggests two different energy mixes depending on the method used.

The first method suggests an energy mix of wind, PV, heat pumps, electric boiler and storage facilities electricity, whereas the installed wind capacity corresponds to around $37 \mathrm{MW}$.

The second method a mix of wind, PV, heat pumps, electric boiler, hydrogen electrolyser, hydrogen fuel cell and storage facilities electricity, whereas the installed wind capacity corresponds to around $65 \mathrm{MW}$.

In the presentation of hydrogen, in section 6.2 .3 , the estimated price of $100 \%$ wind energy supply was EUR 413 million corresponding to 100 pieces $3 \mathrm{MW}$ turbines. In addition, there would be a need for massive storage facilities.

\section{Discussion and considerations}

Wind has already been mentioned multiple times. An energy mix with e.g. hydrogen as base load and wind with battery storage could serve as a good energy system.

Wind power is necessary if eliminating fossil fuels and limiting the import of bio fuels. The only other local and renewable energy source is solar power, which is not available at all during winter.

When using wind power as the main electricity production unit some energy storage will be necessary along with smart use of energy. With wind power (or solar) as the main energy source the rest of the energy system needs to be electrified. The transportation sector (land and sea) and heating sector can support the smart use of energy. The heating sector will be able to use relative low cost energy storages (hot water tanks). However, electricity storages such as batteries and/or hydrogen will also be necessary.

Table 47: Wind energy - summary

\begin{tabular}{ll}
$\begin{array}{l}\text { Wind energy } \\
\text { Cost (per MWh or kWh) }\end{array}$ & $\begin{array}{l}\text { High investment costs, but relatively low running costs once established. } \\
\text { Also requires investment in additional technologies for an optimal working energy system. }\end{array}$ \\
\hline Maturity of technology & Very mature technology. \\
\hline Security of supply & High security in winter time, but cannot stand alone.
\end{tabular}

\subsubsection{Battery storage}

The presentation "Batterier som energilager" (Batteries as energy storage), by Tommy Mokkelbost, SINTEF. ${ }^{68}$

${ }^{68}$ http://www.sintef.no/contentassets/275dae666db8496aa5e8936379odac78/11-batterier-som-energilagermokkelbost.pdf 
In the presentation from the conference there are several examples of batteries in operation in Alaska and Canada, of which a battery solution of 1.2 MW is installed to level out fluctuations in the wind energy production.

In the presentation of hydrogen, in section 6.2.3, the estimated price of $8.5 \mathrm{GWh}$ of battery storage is estimated to be EUR 1-2 billion.

\section{Discussion and considerations}

Storing of energy would be necessary in Svalbard if the primary energy sources to be installed are fluctuating. Storing facilities are important as a means to reduce fossil fuel based emissions, as they remove some of the issues with fluctuations between supply and demand that occur with renewable energy technologies such as wind and solar. Storage capacity can be increased gradually to reflect the supply and demand conditions.

The need for batteries in connection with wind or solar energy needs to be closely assessed, taking into account the installed capacity of wind or solar, potential of heat storage, electricity and heat load profiles and, of course, the installation costs.

Table 48: Battery storage - summary

\section{Battery storage}

\subsubsection{Geothermal energy}

The presentation "Geotermisk energi - en del av framtidens energimiks for Longyearbyen" (Geothermal energy - a part of the future energy mix in Longyearbyen), by Kirsti Midttømme, Christian Michelsen Research AS. ${ }^{69}$

There is potential for geothermal energy in Svalbard. Test drillings have shown a potential of approx. $32^{\circ} \mathrm{C}$ in a depth of 700 meters not far from Longyearbyen.

$69 \mathrm{http} / / /$ www.sintef.no/contentassets/275dae666db8496aa5e8936379odac78/12-2017-06-14-geotermisk-energi----et- 
Figure 11: Ground source temperature at various depths and drilling sites in Svalbard. (Illustration from the presentation "Geotermisk energi - en del av framtidens energimiks for Longyearbyen", by Kirsti Midttømme, Christian Michelsen Research AS)

\section{Temperature data}

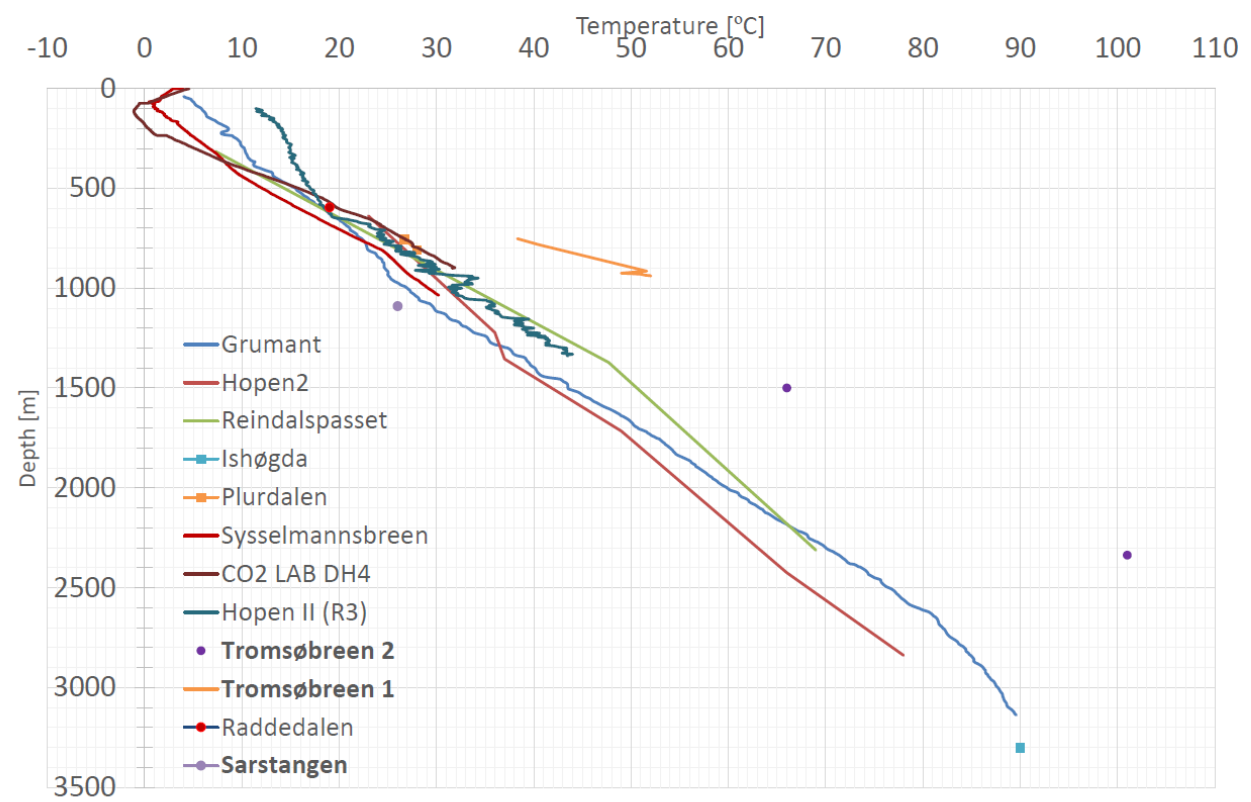

There is already sufficient information to proceed with a full scale test drilling to $2-2.5$ $\mathrm{km}$ depth. At this depth it is expected to find water at temperatures of $60-75^{\circ} \mathrm{C}$.

The ground source temperature is not sufficient to use directly in the existing district heating network, and installing a heat pump is necessary.

The existing district heating network covers most of Longyearbyen. Transformation of the network to a low temperature district heating network would assist the efficient utilization of geothermal energy and streamline the network as a whole.

There are some challenges to the utilization of geothermal energy: There is no existing legislation for geothermal drillings; and the particular composition of the sedimentation means that there could be extra drilling costs.

\section{Discussion and considerations}

Geothermal energy is local energy that is present all year round and can contribute to the present energy production or serve as primary energy production, depending on the ground source available.

It could also be possible to utilize excess heat from the existing energy system and other sources by storing it in the geothermal system. 
Transformation of the existing district heating network seems to be a long term planning period, and is not considered the best option. Installing of heat pump units to raise the temperature of geothermal source to the existing network would be a better solution.

Very few areas in Svalbard have a geothermal source with a temperature over $50^{\circ} \mathrm{C}$, and if a higher temperature is required the corresponding drilling depth will be more than 1,500 meters, as shown in Figure 11. It could be helpful to keep a drilling depth of approx. 1,000 meters and use heat pumps to increase the temperature to district heating level. This will provide a relatively high efficiency and surplus electricity generation from wind power could be used by the heat pumps.

The missing legislation in the area could be a challenging process for penetration of geothermal energy in Svalbard.

There will be a need for stable and secure electricity production capacity, as geothermal energy at the present temperatures on Svalbard is not sufficient for electricity production. It would also be a good technology to combine with fluctuating energy sources as wind and solar energy together with heat and battery storage.

Table 49: Geothermal energy - summary

Geothermal energy

Cost (per MWh or kWh)

Maturity of technology

High investment costs.

Security of supply

\subsubsection{Bio-coal}

The presentation "Arba Follum: Fremtidens energiforsyning i Longyearbyen" (Arba Follum: The future energy supply in Longyearbyen), by Ole Petter Løbben, Arba Follum. ${ }^{70}$

Bio-coal is biomass that has undergone processing to have higher energy content. It is presented as a coal substitute, which makes it possible to continue to run the existing coalfired plant.

The technology for producing bio-coal is new, and operation is planned to start in 2019 after a testing period.

Bio-coal would need to be imported and sufficient storage facilities would need to be established to ensure security of supply in case imports are not available for a period of time.

\section{Discussion and considerations}

The main advantage of bio-coal is that it can be used in the existing facilities with minimum investment, although storage facilities will be required.

70 http://www.sintef.no/contentassets/275dae666db8496aa5e8936379odac78/13-arba-follum---longyearbyen-juni-2017.pdf 
With sufficient storage and a secure supply chain, bio-coal can offer continued security of energy supply to Longyearbyen.

The main disadvantages of bio-coal are that it needs to be imported and it is not totally carbon neutral due to carbon emissions related to processing and transport.

Bio-coal could be used as a transitional technology if it is necessary to bridge the gap between coal and renewable energy, but it is not considered to be a long term sustainable solution for Svalbard.

Table 50: Bio-coal - summary

\begin{tabular}{|c|c|}
\hline \multicolumn{2}{|l|}{ Bio-coal } \\
\hline Cost (per MWh or kWh) & $\begin{array}{l}\text { Low investment costs. } \\
\text { Because the fuel is not yet under production, it is impossible to know what the actual fuel } \\
\text { costs will be. * }\end{array}$ \\
\hline Maturity of technology & On test stage since 2003 , in Norway. \\
\hline Security of supply & High security of supply. Base load. \\
\hline
\end{tabular}

\subsubsection{Carbon capture and storage}

The presentation "UNIS $\mathrm{CO}_{2}$ Lab of Artic Norway - Coal power with $\mathrm{CO}_{2}$ storage?", by Kim Senger et al., UNIS. ${ }^{11}$

In 2007, a project was initiated assessing the possibilities of carbon capture and storage in Svalbard, and phase II was completed in 2015.

The geography for storage of $\mathrm{CO}_{2}$ is present in Svalbard. And it does not conflict with any land use.

The coal source, $\mathrm{CO}_{2}$ storage site and the power plant are all within a radius of $7 \mathrm{~km}$.

\section{Discussion and considerations}

Carbon capture and storage is only relevant if the lifetime of the coal mine should be extended. Coal mining in Svalbard has been decreasing in recent years due to the falling price of coal in conjunction with the coal mines reaching nearing the end of their viable lifetime. It is understood, that one mine is kept open to supply the local demand for coal in Longyearbyen, and this is likely to become less viable as all other mining activities in Svalbard shut down. If it is the case that the coal mine will close due to other reasons than $\mathrm{CO}_{2}$ emissions, then carbon capture and storage technology is not a viable investment. 
Table 51: Carbon capture and storage - summary

Carbon capture and storage

Cost (per MWh or kWh) High investment costs.

If maintaining the coal extraction at Svalbard the technology could be relevant.

Maturity of technology The technologies needed for a CCS system is well developed and known. However because of the high investment costs not many plants are established.

Security of supply

Since the technology in itself is not a production facility a shutdown of the facility would lead to a $\mathrm{CO}_{2}$ emission but not affect the energy production from the coal fired plant.

\subsubsection{Energy efficient buildings and neighbourhoods}

The presentation "Zero emissions buildings and neighborhoods", by Igor Sartori, SINTEF. ${ }^{72}$

It is presented that the potential for energy efficiency (heating) in buildings in 20 years in Longyear was presented to be $50 \%$ lower than today, when residents and building stock increases by $50 \%$ compared to today.

New buildings can be supplied with low temperature district heating on return and the district heating network does not need to be expanded.

\section{Discussion and considerations}

Lowering the energy consumption is in general an advantage for the energy system. However, the energy demand will never be zero, and there is still a need for transition to alternative energy production when the coal mine closes.

In the scenario analysis in the main project, quite comprehensive energy efficiencies are introduced. This is due to the relative high cost of energy.

Transforming parts of the existing district heating network to low temperature district heating will be an advantage for geothermal energy, and heat pumps in general.

Table 52: Energy efficient buildings and neighbourhoods - summary

Energy efficient buildings and neighbourhoods

Cost (per MWh or kWh)

Maturity of technology

Security of supply
Energy efficiencies in buildings is quite low compared with establishing renewable energy generation and storage facilities. However, the feasible energy efficiency projects will only decrease the consumption to some extent.

Energy efficient building components are very well developed and for many buildings should be easy accessible.

Energy efficiency is not a supply or storage technology.

72 http://www.sintef.no/contentassets/275dae666db8496aa5e8936379odac78/15-zero-emissions-buildings-andneighborhoods.pdf 


\subsection{Summary}

As an isolated community located in an area with a relatively harsh climate, security of supply of both heat and electricity is of paramount importance and should be the first consideration in energy supply for Svalbard. Up until now, Svalbard has been supplied with both heat and electricity via a local and readily available source. Whilst it is recognized that this needs to change, it is worth noting that in cases where there is no readily available back-up, a transitional period will be necessary.

In the long term, a mix of renewable energy technologies could provide a secure and sustainable supply. For example:

- In the winter months, wind turbines could provide electricity directly and also to a heat pump, and/or direct electrical boilers within a thermal storage tank;

- Heat pumps connected to geothermal could provide baseline heat;

- Both heat and electricity storage would be needed, either directly or via a medium such as hydrogen.

- $\quad P V$ 's providing electricity during the summer months for direct use and to power a heat pump for geothermal could be relevant to some degree. This is however expected to be quite limited in a fossil free energy system because of the seasonal restrictions.

The actual mix of technologies that is right for Svalbard will require further assessment and consideration, and most likely a period of trial and testing. Switching to such a technology mix in a sensitive and isolated area is not a quick process and requires planning and political support. Financing will also be a key consideration, as many of the technologies have high capital costs.

Whilst transitioning to a fully renewable supply a reliable backup will be needed. This should be a resource, which can be stored and utilized on demand, so that it can be called upon as necessary. Depending on the lifetime of the existing coal supply and generation equipment, the existing energy supply could be maintained during a transitional period. Resources that can be stored and used in the existing generation plant could also be a benefit during transition, for example bio-coal or another form of biomass-based fuel. Whilst these do not offer long term self-sufficiency for Svalbard, they would provide an interim solution whilst alternatives are installed and proven.

Summarized below are the main advantages and disadvantages of the various options discussed. As mentioned above, the final mix will depend on a number of factors, but will need to ensure a stable and sustainable supply of energy to Svalbard in the long term. 
Table 53: Potential Energy technologies for Svalbard

\begin{tabular}{|c|c|c|c|}
\hline Technology & Energy type & Advantages & Disadvantages \\
\hline Solar panels (PV) & $\begin{array}{l}\text { Electricity to grid and } \\
\text { potential power to heat } \\
\text { pump }\end{array}$ & $\begin{array}{l}\text { Base load during summer, } \\
\text { no carbon emission }\end{array}$ & $\begin{array}{l}\text { Only potential during } \\
\text { summer }\end{array}$ \\
\hline Wind Energy & $\begin{array}{l}\text { Electricity to grid and } \\
\text { potential power to heat } \\
\text { pump }\end{array}$ & $\begin{array}{l}\text { Base load during winter, no } \\
\text { carbon emission }\end{array}$ & $\begin{array}{l}\text { Most potential during } \\
\text { winter }\end{array}$ \\
\hline $\begin{array}{l}\text { Geothermal for heat } \\
\text { demand with heat pump }\end{array}$ & Heat supply & $\begin{array}{l}\text { Base load, high security of } \\
\text { supply, no carbon emission }\end{array}$ & $\begin{array}{l}\text { High initial costs, efficiency } \\
\text { is very sensitive to source } \\
\text { temperature and required } \\
\text { supply temperature }\end{array}$ \\
\hline $\begin{array}{l}\text { Diesel generator for peak } \\
\text { and back-up capacity }\end{array}$ & $\begin{array}{l}\text { Electricity and potentially } \\
\text { heat via CHP operation }\end{array}$ & High security of supply & $\begin{array}{l}\text { Carbon emission, } \\
\text { dependent on import of } \\
\text { fuel }\end{array}$ \\
\hline $\begin{array}{l}\text { Cable from mainland } \\
\text { Norway }\end{array}$ & $\begin{array}{l}\text { Electricity and potentially } \\
\text { heat via electric heating } \\
\text { and/or heat pump } \\
\text { operation }\end{array}$ & $\begin{array}{l}\text { Secure supply and carbon } \\
\text { neutral if electricity from } \\
\text { Hydropower }\end{array}$ & $\begin{array}{l}\text { High investment cost and } \\
\text { political decision }\end{array}$ \\
\hline Biomass / Bio-coal & Electricity and heat & $\begin{array}{l}\text { High security of supply, can } \\
\text { be used in existing plant } \\
\text { with minimal alterations }\end{array}$ & $\begin{array}{l}\text { Needs to be imported. } \\
\text { Although low carbon, not } \\
\text { totally carbon neutral }\end{array}$ \\
\hline Hydrogen & $\begin{array}{l}\text { Electricity, heat and } \\
\text { transport sector }\end{array}$ & No carbon emission & $\begin{array}{l}\text { Dependent on import of } \\
\text { fuel }\end{array}$ \\
\hline LNG & $\begin{array}{l}\text { Electricity, heat and } \\
\text { transport sector }\end{array}$ & $\begin{array}{l}\text { Can be stored and used } \\
\text { when necessary }\end{array}$ & $\begin{array}{l}\text { Needs to be imported, not } \\
\text { carbon neutral }\end{array}$ \\
\hline Battery storage & Electricity Storage & $\begin{array}{l}\text { Increased flexibility and } \\
\text { security of supply }\end{array}$ & \\
\hline Heat storage water tanks & $\begin{array}{l}\text { Storage of heat and } \\
\text { potential for use of } \\
\text { oversupply of wind power }\end{array}$ & $\begin{array}{l}\text { Increased flexibility of } \\
\text { heating system }\end{array}$ & \\
\hline Energy efficient buildings & & $\begin{array}{l}\text { Decrease in demand and } \\
\text { carbon emission }\end{array}$ & $\begin{array}{l}\text { High initial costs, if } \\
\text { buildings do not need } \\
\text { refurbishment }\end{array}$ \\
\hline
\end{tabular}




\subsection{Data and Literature}

\subsubsection{Case study-Transportation:}

http://ucsdnews.ucsd.edu/pressrelease/electrolytes_made_from_liquefied_gas_enable_batteri es_to_run_at_ultra_low

https://www.tu.no/artikler/denne-norske-teknologien-kan-gi-elbilbatterier-som-ikke-farmindre-kapasitet-i-kulda/408421?utm_source=newsletter-2017-10o3\&utm_medium=email\&utm_campaign=newsletter

"A Comprehensive Review of Solutions and Strategies for Cold Start of Automotive Proton Exchange Membrane Fuel Cells", Amanou et al, IEEE Volume 4, 2016

https://www.autoblog.com/2014/02/06/toyota-says-freezing-temps-pose-zero-problems-forfuel-cell-vehi/

http://www.hybridcars.com/toyotas-fuel-cell-vehicles-can-handle-the-cold/

http://www.roadandtrack.com/new-cars/car-technology/a10375356/this-electric-truck-is-thefuture-of-off-roading/

http://bollingermotors.com/

http://www.roadandtrack.com/new-cars/future-cars/a12844641/expect-more-off-road-andelectrified-vehicles-from-ford/

http://cs.amsnow.com/sno/b/news/archive/2017/04/21/electric-snowmobile-here-to-stay.aspx https://electrek.co/2017/04/18/all-electric-snowmobiles-taiga-motors/

http://www.linkkerbus.com/technology/

http://www.linkkerbus.com/updates/

http://www.volvobuses.co.uk/en-gb/our-offering/buses/volvo-79oo-electric.html

http://www.volvobuses.com/en-en/news/2017/sep/Volvo-receives-largest-ever-order-of-fullyelectric-buses-for-trondheim.html

http://newsroom.toyota.co.jp/en/detail/15160167

https://newatlas.com/toyota-sora-fuel-cell-bus-tokyo/51825/

https://paultan.org/2017/10/20/toyota-sora-fuel-cell-bus-concept-with-200-km-range/

https://www.daimler.com/products/trucks/mercedes-benz/world-premiere-mercedes-benzelectric-truck.html

https://www.mercedes-benz.com/en/mercedes-benz/next/e-mobility/e-truck-rolls-in-series/

https://www.daimler.com/products/trucks/fuso/ecanter.html

http://www.sea-electric.com/ev-10/, http://www.sea-electric.com/ev-14/

https://electrek.co/2017/10/25/daimler-heavy-duty-electric-truck-concept/

https://www.daimler.com/innovation/case/electric/efuso-2.html

https://www.trucks.com/2017/04/19/toyota-project-portal-fuel-cell-truck-technology/

https://www.theverge.com/2017/10/12/16461412/toyota-hydrogen-fuel-cell-truck-port-la

https://www.trucks.com/2017/11/og/nikola-fuel-cell-truck-field-test-2018/

https://arstechnica.com/cars/2017/og/nikola-motor-company-and-bosch-team-up-on-longhaul-fuel-cell-truck/

https://nikolamotor.com/one

\subsubsection{Case study-Igaliku}

http://www.stat.gl/publ/kl/GF/2017/pdf/Greenland\%2oin\%2oFigures\%202017.pdf

http://bank.stat.gl/pxweb/da/Greenland/Greenland_BE_BEo1_BE0120/BEXST4.PX/?rxid=bd a73178-5f85-4ec4-98ge-9402c8bcfgd1 


\subsubsection{Case study - Fishing vessels}

http://www.nordicenergy.org/wp-content/uploads/2016/04/Nordic-Energy-Technology-

Perspectives-2016.pdf

https://www.siemens.com/press/en/feature/2015/corporate/2015-05-e-ferry.php

https://www.siemens.com/press/en/feature/2015/corporate/2015-05-e-ferry.php

https://www.siemens.com/press/en/feature/2015/corporate/2015-05-e-ferry.php

https://www.siemens.com/press/IG2017030032COEN

https://www.siemens.com/press/PR2017020187PDEN

https://www.siemens.com/press/pool/de/feature/2015/corporate/2015-05-e-ferry/mediaservice-anchors-aweigh-e.pdf

https://www.siemens.com/press/pool/de/feature/2015/corporate/2015-05-e-ferry/mediaservice-anchors-aweigh-e.pdf

https://maritime-executive.com/article/worlds-first-hydrogen-powered-cruise-ship-scheduled http://www.motorship.com/news101/fuels-and-oils/cutting-through-the-hydrogen-hype http://www.seafish.org/media/Publications/FS27_04.09_Fuel_emissions.pdf

http://network.bellona.org/content/uploads/sites/2/2017/08/Elektrifisering-avkystfiskeflaten.pdf?_utma $=123600408.1203258448 .1501756656 .1502784911 .1502791637 .21 \&$ _utmb $=123600408.0 .10 .1502791637 \&$ _utmc $=123600408 \&$ _utmx=-

\&_utmz=123600408.1502192186.7.2.utmcsr=google|utmccn=(organic)|utmcmd=organic|utm $\mathrm{ctr}=($ not\%2oprovided)\&_utmv $=-$ \&_utmk $=157751482$

http://www.nordicenergy.org/wp-content/uploads/2016/04/Nordic-Energy-TechnologyPerspectives-2016.p

\subsubsection{Case study - Tourism}

National statistics of the Faroe Islands: www.hagstofa.fo

Overnight stay on hotel, hostel, Guest-house by purpose, region and country of residence (VVo7020_GIST_HUS)

Passenger transport to and from the Faroe Islands, by air and sea (SS01010_FERD_SJOLOFT) National statistics of Greenland: www.stat.gl

Flypassagerer, der rejser fra Grønland (Charter og rutefly) efter lufthavn, bopæl, måned og tid (TUXFLY)

Antal udenrigspassagerer på rutefly efter lufthavn, måned og tid (TUXPAX)

Hotelovernatninger efter måned, nationalitet, region, enhed og tid (TUXHOT)

Antal togter fordelt på passagerkapacitet efter tid, måned og kapacitet (TUXKRK)

Faktisk energiforbrug fordelt på nationalregnskabets branchekoder efter enhed, energivare, branche og tid (ENE2FBR)

National statistics of Iceland: www.statice.is

Passengers through Keflavik airport by citizenship and month 2002-2017 (SAMo2001)

Passengers from abroad on luxury liners at the Port of Reykjavík (SAM02002)

Production accounts of tourism and other industries 2009-2015 (SAMo80039

Inbound tourism expenditure in Iceland by consumption products and classes of visitors, 20092016 (SAMo8000)

Overnight stays and arrivals in all types of accommodation 1998-2016 (SAMo1601)

National statistics of Norway: www.ssb.no

Air transport. Passengers, by airport, type of traffic, traffic, passenger group, time and contents (8508-1)

Svalbard. Industry statistics, by main industry (SIC 2007) (SSB) 
Tourism in the Polar Regions, The Sustainability Challenge - UNEP \& the International Ecotourism Society (2007)

Economy of Iceland - The Central Bank of Iceland (2016)

http://journals.openedition.org/etudescaribeennes/3487

Energy tourism: An emerging field of Study - B. Frantál \& R. Urbánková (2014):

http://www.tandfonline.com/eprint/68a5amNtr3Phe2UvnmcR/full

Carbon Management in Tourism: Mitigating the impacts on climate change - S Gössling (2011): https://books.google.dk/books?id=ZnOMAgAAQBAJ\&pg=PT191\&lpg=PT191\&dq=kwh+overni ght+stay\&source=bl\&ots=SzQwOMOtTG\&sig=aeD ${ }_{5}$ CuZaCsTib3ogXKF-ks-

htdo\&hl=da\&sa=X\&ved=oahUKEwjw3de75LvYAhVDMZoKHYqZCaAO6AEIKTAA\#v=onepage $\& q=k w h \%$ 2oovernight\%2ostay\&f=false

Iceland: A truly sustainable destination: http://mynatour.org/destination/iceland-trulysustainable-destination

Icehotel in Sweden: https://www.icehotel.com/about-icehotel/sustainability/

Solar panels with the constant sun to keep the hotel cool during the summer.

Figure over energy consumption in hotels: https://www.construction21.org/articles/h/optimiseenergy-management-in-hotels.html

Carbon Footprint calculator: http://calculator.carbonfootprint.com/calculator.aspx?tab=3

\subsubsection{Case study-Decarbonising Svalbard}

http://www.sintef.no/arrangementer/fremtidens-energiforsyning-i-longyearbyen/ http://www.uib.no/en/energy/113294/modelling-future-energy-system-longyearbyen$\% \mathrm{E}_{2} \% 80 \% 93$-hans-kristian-ringkj\%C3\%B8b-gfi

http://www.sintef.no/contentassets/275dae666db8496aa5e8936379odac78/05-12062017_elektrifisering-av-svalbard_sintef-workshop-1.pdf

http://www.sintef.no/contentassets/275dae666db8496aa5e8936379odac78/o6-hv--11062017fremtidsrettet-infrastruktur--for-longyearbyen-hybrid.pdf

http://www.sintef.no/contentassets/275dae666db8496aa5e8936379odac78/07-

20170612_hydrogen_svalbard_odegard_kortversjon_til-pdf.pdf

http://www.sintef.no/contentassets/275dae666db8496aa5e8936379odac78/o8-svalbardpresentasjon-sandberg.pdf

http://www.sintef.no/contentassets/275dae666db8496aa5e8936379odac78/10--130755--thorud---fremtidens-energisystem-i-longyearbyen-publ.pdf

http://www.uib.no/sites/w3.uib.no/files/attachments/hans-kristian_ringkjob_o.pdf

http://www.sintef.no/contentassets/275dae666db8496aa5e8936379odac78/11-batterier-somenergilager-mokkelbost.pdf

http://www.sintef.no/contentassets/275dae666db8496aa5e8936379odac78/12-2017-06-14geotermisk-energi----et-alternativ-for-svalbard.pdf

http://www.sintef.no/contentassets/275dae666db8496aa5e8936379odac78/13-arba-follum--longyearbyen-juni-2017.pdf

http://www.sintef.no/contentassets/275dae666db8496aa5e8936379odac78/14---. unis_co2_lab_energiseminaret_lyr.pdf

http://www.sintef.no/contentassets/275dae666db8496aa5e8936379odac78/15-zero-emissionsbuildings-and-neighborhoods.pdf 


\section{Sammenfatning}

\section{Case study}

I forbindelse med analysen af den fremtidige energiforsyning af Vestnorden og det arktiske er der blevet foretaget fem case studies. Studierne er alle relevante for denne karakteristiske region, hvor forhold som kulde, mindre energisystemer og begrænsede adgang til brændsler er med til at udfordre og begrænse mulighederne for at overgå til lavemissionssamfund. De fem studier er:

- Land transport

- Igaliku energiforsyning (et mindre intelligent energisystem I Grønland)

- Elektrificering af fiskerbåde

- Turisme

- Det fremtidige energisystem I Svalbard.

De fleste studier er relevante for det meste eller hele regionen.

\section{Land transport}

Konverteringen til en bæredygtig landtransportsektor er en general global udfordring og ikke blot for denne region. Til gengæld findes der her i regionen gode vand- og vindkraftressourcer, som kan være væsentlig til at støtte omstillingen til bæredygtig landtransport.

Studiet finder, at omkostningerne i regionen i forbindelse med en konvertering til en bæredygtig landtransportsektor vil have meget lave samfundsøkonomiske omkostninger i 2020, mens at det vil have en samfundsøkonomisk fordel i 2030. Dette skyldes i høj grad en forventning om hurtig reduktion af omkostningerne til relevante teknologier samt udviklingen af brændselspriserne.

\section{Igaliku energiforsyning}

I Grønland er de fleste byer/bygder ikke forbundet til et samlet net. Det betyder, at hver enkel by/bygd vil få brug for deres eget skræddersyede intelligente energisystem. Grønlands energiselskab Nukissiorfiit arbejder med et sådan energisystem i Igaliku i Grønland. Dette energisystem kan danne grundlaget for opbygning af tilsvarende intelligente energisystemer i de andre mindre byer/bygder. 
I Igaliku består energisystemet af solceller, vindmøller og et batteri samt dieselgeneratorer. Vindmøller er små møller placeret på toppen af solcellerne. Solcellerne vil have meget høj benyttelsestid om sommeren, hvor solen er oppe det meste af døgnet. Dieselgeneratorerne skal bruges som spids- og reservelast.

\section{Elektrificering af fiskerbåde}

Fiskeindustrien er blandt de sektorer, der udleder mest $\mathrm{CO}_{2}$ i regionen. Her forventes batterier og brændselsceller at være centrale i overgangen til en bæredygtig sektor. Studiet finder, at teknologierne er på vej, men at det stadig er et tidligt stadie. Teknologier til mindre både, der skal på endagsture, forventes at være tilstede i nær fremtid. Udfordringerne bliver de store skibe, især de der skal være væk fra havnen i flere uger.

\section{Turisme}

Regionen er et meget populært rejsemål for turister og er således vigtig for den lokale økonomi. Turismen medfører dog også store energiforbrug.

Turismen som energiforbruger kan udnyttes, hvis man formår at få mere fokus på "ecoturisme", hvor man betaler lidt ekstra for rejsen mod, at overskuddet går til investeringer i vedvarende energi. Især fordi de fleste rejsende tager til regionen for at få naturoplevelser, vurderes det at være realistisk, at turisterne overvejende vil være positive overfor et sådan initiativ.

\section{Det fremtidige energisystem i Svalbard}

Det forventes, at kulminen i Svalbard skal lukkes inden for de næste 10 år. Det vil medføre et behov for væsentlige ændringer af deres nuværende energiforsyning, da kulværket vil blive lukket. Dette kan blive vejen til et bæredygtigt energisystem I Svalbard.

Studiet tager udgangspunkt i en række forslag til fremtidige energiløsninger i Svalbard fra en konference i juni 2017. Løsningerne bliver her i studiet præsenteret og diskuteret. Løsningerne omfatter forsyning med elkabel fra Norge, blanding af LNG og solenergi, hydrogen, solenergi, vindenergi, batterilager, geotermi, biokul, CCS og energieffektivisering i bygninger. Løsningerne vil ikke skulle stå alene, men supplere og støtte hinanden i en samlet forsyning.

Det vurderes, at især en blanding af vindkraft, batterier og geotermivarmepumper vil være en god løsning både økonomisk, men også i form af brugen af kendte teknologier. Hertil kan suppleres med solceller og import af biodiesel eller lignende, således at der kan være reservelast i systemet fra dieselgeneratorer. Flere af de andre forslåede teknologier kan suppleres efter behov og tilgængelighed. Etablering af et kabel fra Norge vurderes dog ikke at være en rentabel løsning. 
Nordic Council of Ministers

Nordens Hus

Ved Stranden 18

DK-1061 Copenhagen

www.norden.org

\section{ENERGY IN THE WEST NORDICS AND THE ARTIC}

This project explores the energy systems and their development towards 2035 in the West Nordic areas and the Arctic. The objective of the project was to contribute to a knowledge base that can be shared and used in developing a sustainable and competitive energy systems that fulfil the goals and obligations for 2035 on climate, emissions and renewable shares. "Energy systems" in this case covers the potential for different renewable energy resources, infrastructure, the demand for energy in different sectors, and relevant policies.

Along with the scenario analysis, five case studies have been developed: land transport; a small hybrid energy system in Igaliku, Greenland; electrification of fishing vessels; tourism; and the future energy system in Svalbard. 